\title{
Influence of Titanium Dioxide Nanoparticles on Human Health and the Environment
}

\author{
Mohammad Mamunur Rashid (D), Petra Forte Tavčer * and Brigita Tomšič * \\ Department of Textiles, Graphic Arts and Design, Faculty of Natural Sciences and Engineering, \\ University of Ljubljana, Aškerčeva 12, 1000 Ljubljana, Slovenia; mamun444@gmail.com \\ * Correspondence: petra.forte@ntf.uni-lj.si (P.F.T.); brigita.tomsic@ntf.uni-lj.si (B.T.)
}

Citation: Rashid, M.M.; Forte Tavčer, P.; Tomšič, B. Influence of Titanium Dioxide Nanoparticles on Human Health and the Environment. Nanomaterials 2021, 11, 2354. https:// doi.org/10.3390/nano11092354

Academic Editor: Thierry Rabilloud

Received: 20 August 2021

Accepted: 8 September 2021

Published: 10 September 2021

Publisher's Note: MDPI stays neutral with regard to jurisdictional claims in published maps and institutional affiliations.

\begin{abstract}
Nanotechnology has enabled tremendous breakthroughs in the development of materials and, nowadays, is well established in various economic fields. Among the various nanomaterials, $\mathrm{TiO}_{2}$ nanoparticles (NPs) occupy a special position, as they are distinguished by their high availability, high photocatalytic activity, and favorable price, which make them useful in the production of paints, plastics, paper, cosmetics, food, furniture, etc. In textiles, $\mathrm{TiO}_{2} \mathrm{NPs}$ are widely used in chemical finishing processes to impart various protective functional properties to the fibers for the production of high-tech textile products with high added value. Such applications contribute to the overall consumption of $\mathrm{TiO}_{2}$ NPs, which gives rise to reasonable considerations about the impact of $\mathrm{TiO}_{2}$ NPs on human health and the environment, and debates regarding whether the extent of the benefits gained from the use of $\mathrm{TiO}_{2}$ NPs justifies the potential risks. In this study, different $\mathrm{TiO}_{2} \mathrm{NPs}$ exposure modes are discussed, and their toxicity mechanisms-evaluated in various in vitro and in vivo studies-are briefly described, considering the molecular interactions with human health and the environment. In addition, in the conclusion of this study, the toxicity and biocompatibility of $\mathrm{TiO}_{2}$ NPs are discussed, along with relevant risk management strategies.
\end{abstract}

Keywords: $\mathrm{TiO}_{2}$; titanium dioxide; human health; environment; toxicity; oxidative stress; biocompatibility; risk management

\section{Introduction}

$\mathrm{TiO}_{2}$ is one of the most abundant and widely used metal oxide nanomaterial in the world [1,2]. As an n-type semiconductor, with a band gap energy of 3.2-3.35 eV, depending on its crystal phase, $\mathrm{TiO}_{2}$ acts as an effective photocatalyst during the photocatalytic process for surface functionalization [3-6]. It has three crystalline structures: anatase, rutile, and brookite. Anatase is the most common type and rutile is the most stable form, while brookite is the rarest [7]. There is also amorphous $\mathrm{TiO}_{2}$, which is a non-crystalline form. $\mathrm{TiO}_{2}$ exists in various nanostructures, such as nanoparticles, nanotubes, nanorods and nanowires, nanofilms, nanosheets, and nanocoatings, with remarkable photocatalytic activity, which attract scientists to develop potential technological applications in multidisciplinary fields for industrial production [8].

$\mathrm{TiO}_{2}$ is widely used in food, paints, plastics, printing inks, papers, and biomedical and cosmetic products. Due to its unique properties, $\mathrm{TiO}_{2}$ is also advantageously used in textiles. For example, when applied to textile fibers, it confers various functionalities such as UV protection, photocatalytic self-cleaning and antimicrobial activity, electrical conductivity, and antistatic properties, as well as increased thermal stability. Moreover, it can also be used for solar energy conversion in the production of electronic textiles or wearable electronics. However, when tailoring its desired functionality, $\mathrm{TiO}_{2}$ is usually deposited on the surface of textile fibers, but due to its fairly poor adhesion to the fibers, a certain amount of $\mathrm{TiO}_{2}$ washes away, peels off, or wears off during the product's lifetime. Therefore, such continuous leaching of $\mathrm{TiO}_{2}$ into the environment results in a potential threat to human health and the ecosystem. 
Extensive use of $\mathrm{TiO}_{2} \mathrm{NPs}$ reasonably raises significant concerns due to their potential nanotoxicity, induced by oxidative stress, which is influenced by ROS (Reactive Oxygen Species) formation on the surface of $\mathrm{TiO}_{2} \mathrm{NPs}$ in the presence of UV light [9-12]. After the penetration of $\mathrm{TiO}_{2} \mathrm{NPs}$ into the human body, inflammation, cytotoxicity, genotoxicity, immunotoxicity, and neurotoxicity may occur. Such nanotoxicity can damage the liver, kidneys, lungs, and skin. Special attention must be paid to production workers, in particular, who are in daily contact with high concentrations of $\mathrm{TiO}_{2} \mathrm{NPs}$. For instance, it has been proven that $\mathrm{TiO}_{2} \mathrm{NPs}$ smaller than $20 \mathrm{~nm}$ cause a higher inflammatory response in human cells [13]. Furthermore, $\mathrm{TiO}_{2} \mathrm{NPs}$ also pose certain damage to end users and researchers and, at lower concentrations, $\mathrm{TiO}_{2} \mathrm{NPs}$ act as immunomodulatory agents, inducing inflammatory responses through specific interactions with immune system cells $[14,15]$.

Undoubtedly, $\mathrm{TiO}_{2}$ is released into most ecosystems, including in the agricultural field, where its potential effects on soil properties, soil microflora, and plants are yet to be investigated. However, $\mathrm{TiO}_{2}{ }^{\prime}$ s potential nanotoxicity to the aquatic ecosystem is currently under study, and has thus far revealed that $\mathrm{TiO}_{2}$ NPs negatively affect the suppression of the immune system of fish and invertebrates. Despite this, more research is needed to address the bioaccumulation profile of $\mathrm{TiO}_{2}$ and its associated biomagnification in the food web. To date, controversial results have been found when studying the toxicity of $\mathrm{TiO}_{2}$ NPs, which may be due to different particle sizes, doses, culture media, or test methods used $[7,16]$. Recently, green nanotechnology has been adopted by researchers to ensure the biocompatible and environmentally friendly use of $\mathrm{TiO}_{2} \mathrm{NPs}$ by overcoming their drawbacks.

Due to the widespread use of $\mathrm{TiO}_{2}$, exposure to NPs by ingestion, inhalation, or sorption has become virtually inevitable. In the last five years, reviews have been published on the effects of $\mathrm{TiO}_{2} \mathrm{NPs}$ in living organisms, focusing either on the toxicology of $\mathrm{TiO}_{2}$ NPs [1,2,11,17-23], safety concerns in various applications [24-28] and related impact on human health [28-33], or their effects on water/soil/environmental quality [34-38]. Such review studies are necessary to conclusively determine the environmental and human effects of $\mathrm{TiO}_{2} \mathrm{NPs}$. The purpose of this paper is to review recent advances in the potential health and environmental effects of $\mathrm{TiO}_{2} \mathrm{NPs}$ in order to contribute to the establishment of a scientific basis for the safe application of $\mathrm{TiO}_{2} \mathrm{NP}$ and to promote the sustainable development of nanotechnology. Accordingly, the main exposure modes of $\mathrm{TiO}_{2} \mathrm{NPs}$, their potential toxicity mechanisms on human cells through various signaling pathways along with the negotiable toxicity, the health effects of exposure to $\mathrm{TiO}_{2} \mathrm{NPs}$, the biocompatibility, and the environmental effects of $\mathrm{TiO}_{2} \mathrm{NPs}$ are discussed in detail.

\section{Modes of Exposure}

\subsection{Inhalation}

Inhalation is the major route of nanoparticle penetration into the body [33,39]. When $\mathrm{TiO}_{2} \mathrm{NPs}$ are inhaled, they are transported to various lung tissues, capillaries, airways, and alveoli and translocated to the heart, liver, nervous system, etc. [13]. Depending on the duration and concentration of inhalation, $\mathrm{TiO}_{2} \mathrm{NPs}$ undergo short- and/or longterm clearance from bodily compartments. By inhalation, finer particles, such as anatase $\mathrm{TiO}_{2} \mathrm{NPs}$, have a more toxic effect than the comparatively coarser rutile form [40]. For a short-term, single-cycle inhalation threshold, a value of $3.5 \mathrm{mg} / \mathrm{m}^{3}$ is assumed for spray applications. For repeated inhalation, a threshold of $17 \mathrm{mg} / \mathrm{m}^{3}$ is assumed for an $8-\mathrm{h}$ workday. In reality, however, the actual threshold is likely to be even higher. Nevertheless, it was shown that an inhalation concentration of up to $35 \mathrm{mg} / \mathrm{m}^{3}$ does not lead to chronic pulmonary overload [40].

\subsection{Oral Route}

$\mathrm{TiO}_{2} \mathrm{NPs}$ can enter the blood via the oral route as they are used in foods, personal care products, sunscreens, and toothpaste. $\mathrm{TiO}_{2} \mathrm{NPs}$ remain in the major organs for a long time and are eventually excreted in the stool. Absorbed $\mathrm{TiO}_{2} \mathrm{NPs}$ in the liver, spleen, kidney, 
and lung tissues are responsible for possible nephrotoxicity and liver damage [41]. Even after the prolonged release of NPs, they can affect living organisms in the environment via biological pathways [42].

\subsection{Dermal Route}

Human skin has unique barrier properties that act against the penetration of $\mathrm{TiO}_{2}$ NPs into the skin. Several studies have found that $\mathrm{TiO}_{2} \mathrm{NPs}$ cannot penetrate through the human dermis, even when their particle size is smaller than $100 \mathrm{~nm}$ [43]. Moreover, other studies have revealed that the $\mathrm{TiO}_{2} \mathrm{NPs}$ that do manage to penetrate the skin do not exhibit toxicity under certain conditions [44].

\subsection{Injection}

$\mathrm{TiO}_{2} \mathrm{NPs}$ can be developed as a highly efficient photothermal, medicinal, and synergistic agent to repair/remove diseased tissues such as cancer both in vitro and in vivo with negligible toxic properties, tissue damage, and kidney/liver dysfunction [45,46]. After injection of $\mathrm{TiO}_{2}$ NPs, endothelial cells can be disrupted, and they can proliferate and migrate despite the induction of toxicity and immunogenicity. It has been shown that $\mathrm{TiO}_{2}$ NPs injected into the blood during photothermal cancer therapy enrich the cancer tissue by diffusing, engulfing the cancer cells, and eventually killing them completely [47-49].

\section{Toxicity of $\mathrm{TiO}_{2} \mathrm{NPs}$}

There is a lack of information on the potential toxicity of $\mathrm{TiO}_{2} \mathrm{NPs}$. Indeed, despite numerous studies in this field, it is difficult to find separate studies using the same $\mathrm{TiO}_{2}$ NPs with the same experimental protocol to compare the results obtained. Nevertheless, the existing data support the potential toxicity of $\mathrm{TiO}_{2} \mathrm{NPs}$ in humans, model vertebrates and invertebrates, plants, algae, and microorganisms. The mechanism of toxicity of $\mathrm{TiO}_{2}$ NPs to organisms can be outlined as follows: (i) production of reactive oxygen species (ROS) and formation of electron-hole pairs in the presence of light; (ii) binding of $\mathrm{TiO}_{2}$ NPs to the cell membrane via electrostatic interactions, resulting in cell wall damage and peroxidation of lipids in the cell membrane; and (iii) binding of $\mathrm{TiO}_{2} \mathrm{NPs}$ to intracellular organelles and biological macromolecules [50].

\subsection{Cytotoxicity}

It is well known that $\operatorname{ROS}$ (i.e., superoxide $\left(\mathrm{O}_{2}{ }^{\bullet-}\right)$, hydrogen peroxide $\left(\mathrm{H}_{2} \mathrm{O}_{2}\right)$, and the hydroxyl radical $\left.\left(\mathrm{OH}^{-}\right)\right)$are produced by aerobic organisms within the cell and are normally in equilibrium with antioxidant molecules (Figure 1a) [51]. The imbalance between ROS and antioxidants (AOX) caused by the excessive production of ROS or the depletion of antioxidant molecules leads to the occurrence of oxidative stress (Figure 1b,c) [51].
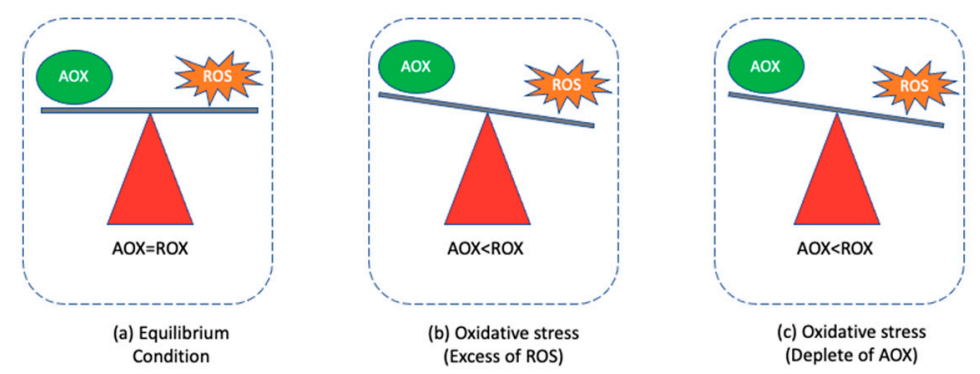

Figure 1. Equilibrium of ROS and antioxidants (AOX) (a) and their disequilibrium causing oxidative stress, either by an excess of ROS (b) or a deficiency of AOX (c).

As for the negative biological effects, oxidative stress is the most important process involved in the formation of $\mathrm{TiO}_{2} \mathrm{NPs}$-induced ROS [52]. High $\mathrm{TiO}_{2}$ concentrations cause greater oxidative stress, which correlates with the increase in lipid peroxidation at the cell membrane after $\mathrm{TiO}_{2} \mathrm{NPs}$ adsorption on the cell membrane. $\mathrm{TiO}_{2} \mathrm{NPs}$-induced ROS 
and lipid peroxidation damage the integrity of the cell wall and membrane, resulting in increased permeability [53], which allows $\mathrm{TiO}_{2} \mathrm{NPs}$ to enter the cell. In addition to free diffusion, $\mathrm{TiO}_{2} \mathrm{NPs}$ can also enter the cell through the process of endocytosis. While particles larger than $500 \mathrm{~nm}$ can be removed by phagocytes [50], smaller particles can be engulfed by a cell membrane vesicle and taken further into the cell. Accordingly, $\mathrm{TiO}_{2}$ NPs with a size of $25 \mathrm{~nm}$ and less have been taken up into human keratinocytes [54], as well as lung cells [52,55], lymphocytes [56], macrophages [57], keratinocytes [58], and hepatocytes [59] after endocytosis. It is also interesting to note the penetration ability of $\mathrm{TiO}_{2}$ particles with a size of $200 \mathrm{~nm}$ into red blood cells, which were chosen as a model for non-phagocytic cells. The results demonstrated the ability of the particles to penetrate the red blood cell membrane by a mechanism other than phagocytosis and endocytosis [60]. In this case, the penetration mechanism remained unexplained.

Upon entrance of $\mathrm{TiO}_{2} \mathrm{NP}$ into the cell, the internalized $\mathrm{TiO}_{2} \mathrm{NPs}_{\text {se }}$ transported to lysosomes, where they generate lysosomal stress and release cytosol that reacts with cellular components, resulting in DNA damage, DNA rearrangement, altered gene expression, oxidative stress, and inflammation (Figure 2) [28,56,61-63]. $\mathrm{TiO}_{2} \mathrm{NPs}$ impair micromolecular functions by protein adsorption, blocking signaling pathways, and binding to DNA structure [64,65]. Undoubtedly, such damage affects cell viability [66] and is dose and time dependent $[67,68]$.

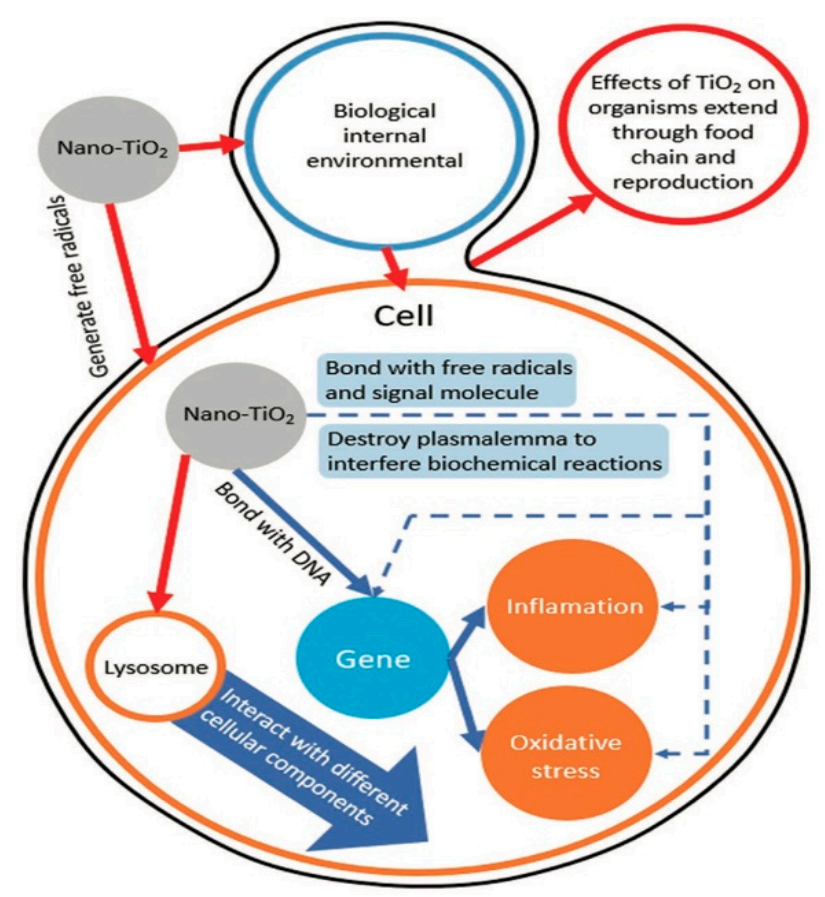

Figure 2. Toxicity mechanism of the reaction of $\mathrm{TiO}_{2} \mathrm{NPs}$ with cells. Adapted with permission from [28]. Copyright, 2020 John Wiley \& Sons, Inc.

It should also be noted that the response of cells in the presence of $\mathrm{TiO}_{2} \mathrm{NPs}$ is complex. Thus, the presence of $\mathrm{TiO}_{2}$ NPs can modulate different cell fates, including necrosis and apoptosis, which are regular cell death pathways, or autophagy, which leads to either cytoprotective mechanisms or cell death (Figure 3) [69]. $\mathrm{TiO}_{2} \mathrm{NP}$-induced autophagy can be exploited in new therapeutic pathway treatment of various diseases (see Section 6). 


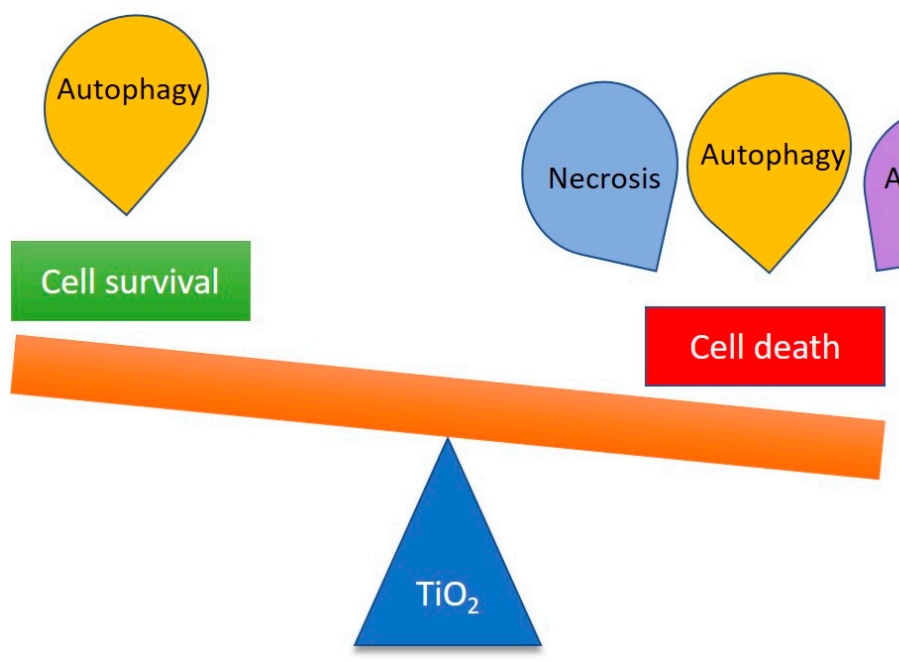

Figure 3. Influence of $\mathrm{TiO}_{2} \mathrm{NPs}$ on the cell fate.

\subsection{Genotoxicity}

The genotoxicity of $\mathrm{TiO}_{2}$ NPs has not yet been clarified as scientists do not have sufficient evidence of genotoxicity [70,71]. Genotoxicity refers to the ability of $\mathrm{TiO}_{2} \mathrm{NPs}$ to disrupt genetic information by causing breaks, lesions, deletions, mis-segregation, or non-disjunction in the DNA, leading to gene mutations. In vitro testing methods, such as mammalian chromosomal aberration tests, cellular gene mutation tests and bacterial reverse mutation tests, are performed to measure genotoxicity [72,73]. In contrast, the in vivo comet assay and the in vivo micronuclei/chromosome aberration assay evaluate in vivo genotoxicity [74]. The genotoxic effect of $\mathrm{TiO}_{2} \mathrm{NPs}$ on cells is mainly studied through the circulatory or respiratory system. Despite the crystallinity of $\mathrm{TiO}_{2} \mathrm{NPs}$, their genotoxicity mostly depends on their particle size. Smaller $\mathrm{TiO}_{2} \mathrm{NPs}$ possess a stronger genotoxic effect than larger ones, as they easily penetrate into the nucleus and cytoplasm of the cell [74]. Larger agglomerations of $\mathrm{TiO}_{2}$ NPs cause DNA damage [75]. Several studies have shown the genotoxic and cytotoxic effects of $\mathrm{TiO}_{2} \mathrm{NPs}$ on human amniotic epithelial cells [76], human lung fibroblasts [77], human lymphocytes [78], and human hepatoma HepG2 cells [79]. In vitro studies of cell-induced genotoxicity caused by $\mathrm{TiO}_{2} \mathrm{NPs}$ due to DNA breakage and gene mutations are shown in Figure 4 [22].

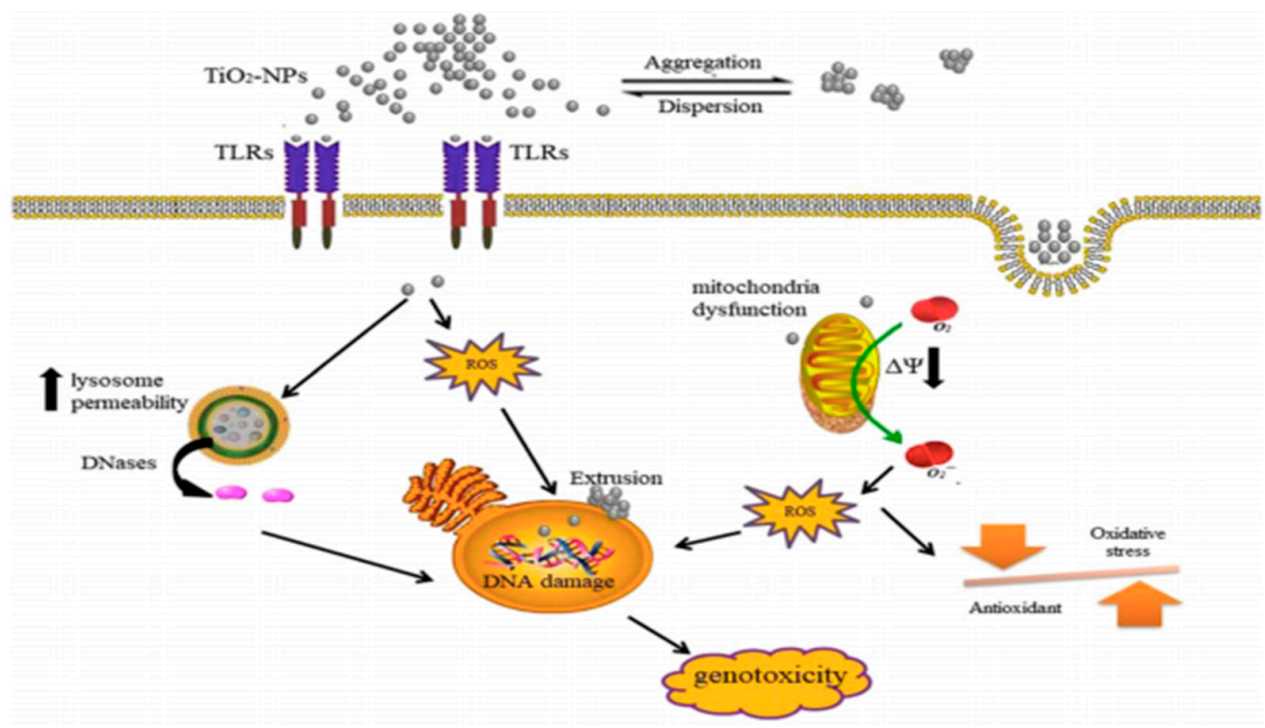

Figure 4. Mechanism of possible genotoxicity of $\mathrm{TiO}_{2} \mathrm{NPs}$ in cells. Adapted with permission from [22]. Copyright, 2021 Sringer Nature. 
Genotoxicity occurs via direct or indirect genotoxicity mechanisms. Namely, $\mathrm{TiO}_{2} \mathrm{NPs}$ can enter the nucleus, inducing direct DNA damage through direct contact with DNA and chromosome, while indirect genotoxicity of $\mathrm{TiO}_{2} \mathrm{NPs}$ results from the increased lysosomal release of DNases, the formation of nanoaggregates that can extrude nucleus or by ROS accumulation. Moreover, $\mathrm{TiO}_{2} \mathrm{NPs}$ can also negatively influence the repair process of DNA. In vitro studies showed the genotoxicity of $\mathrm{TiO}_{2} \mathrm{NPs}$ during short-term exposure, which may be triggered by smaller particle sizes and mixed phases of $\mathrm{TiO}_{2} \mathrm{NPs}$ [22].

Research has provided contradictory results regarding $\mathrm{TiO}_{2} \mathrm{NPs}^{\prime}$ genotoxicity $[7,80]$. Several studies found $\mathrm{TiO}_{2} \mathrm{NPs}$ to have no genotoxic effect $[7,57,80,81]$. Brandão et al. examined $\mathrm{TiO}_{2}$ NP-induced genotoxicity in human lung, liver, glial, and neuron cells [82]. They found no genotoxicity, while $\mathrm{TiO}_{2} \mathrm{NPs}$ were successfully internalized by the experimental cells.

\section{Health Effects of Exposure to $\mathrm{TiO}_{2} \mathrm{NPs}$}

\subsection{Immune System}

The immune system defends the body against foreign antigens. If nanoparticles are recognized as foreign substances, they are eliminated by the immune system. If, on the other hand, the foreign substances are not recognized as a threat, they are either ignored or tolerated by the immune system [83]. The effects of $\mathrm{TiO}_{2} \mathrm{NPs}$ on immune function are poorly documented. Underlying molecular mechanism by which $\mathrm{TiO}_{2} \mathrm{NPs}$ influence the immune cell was studied in relation to TLRs, which are a subfamily of pattern recognition receptors, placed strategically on the cell surface and endosome of primary immune cell macrophages [84]. $\mathrm{TiO}_{2}$-induced immunotoxicity was proven, which occurred through the activation of several receptors, which further activated specific signaling pathways to reduce the antioxidants through the formation of ROS. Upon increased ROS exposure, the mitochondrial membrane potential $(\Delta \psi \mathrm{m})$ reduced, ultimately leading to apoptotic cell death, and inducing immunotoxicity through immune redox imbalance (Figure 5). However, in vivo experiments are essential to further validate $\mathrm{TiO}_{2} \mathrm{NPs}$ influence on the immune system.

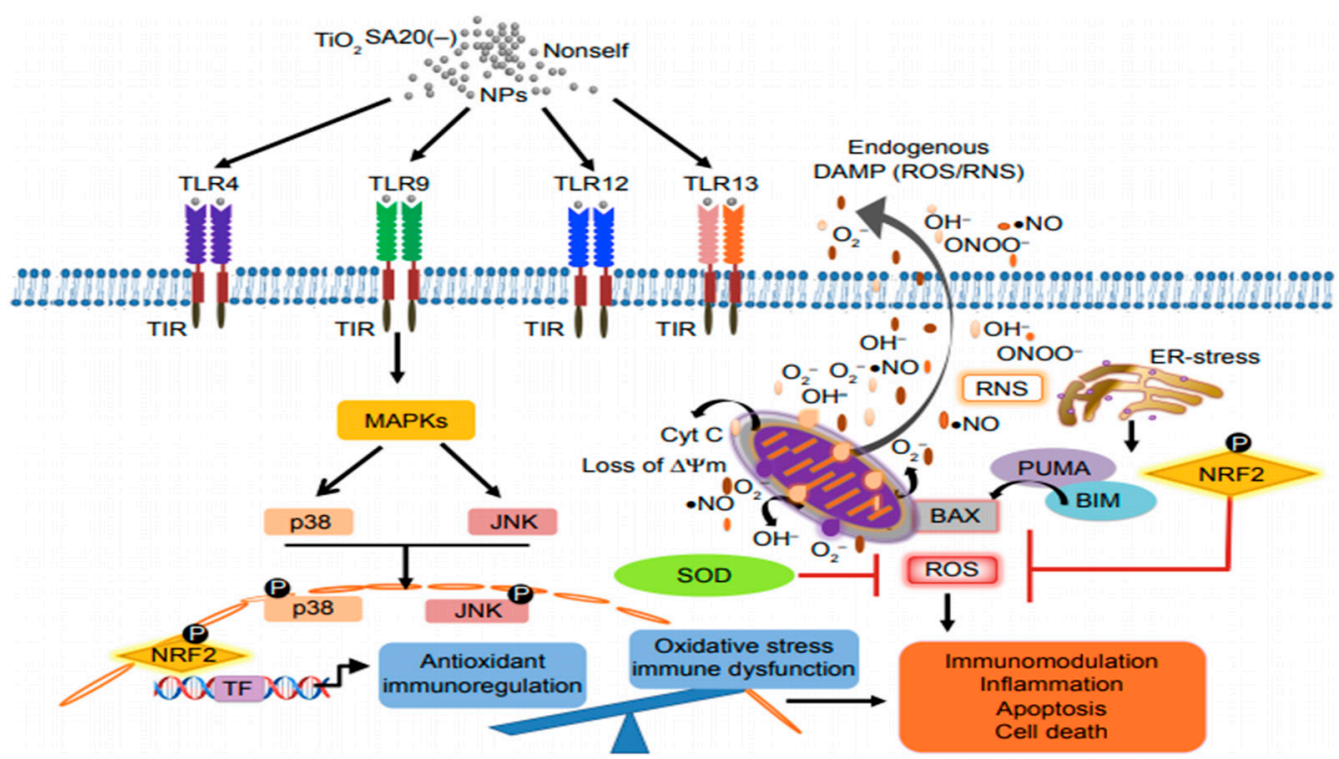

Figure 5. Mechanism of $\mathrm{TiO}_{2} \mathrm{NP}$-induced immunotoxicity in cells (TLR = Toll-like receptor; $\mathrm{MAPK}=$ mitogen-associated protein kinase; JNK = c-jun N-terminal kinase; NRF2 = nuclear factor erythroid 2 factor 2; and SOD = super oxide dismutase). Adapted with permission from [84]. Copyright, 2018 Dove Medical Press Limited. 


\subsection{Neural System}

$\mathrm{TiO}_{2}$ NPs can enter the brain regions by translocation across the blood-brain barrier or thenose-brain barrier, and progeny across the placental barrier, which may be the reason for the dysfunction and potential risks to the central nervous system [32,85-87]. Long-term exposure to $\mathrm{TiO}_{2}$ NPs can cause damages to the neurons and glial cells (U373), which may subsequently lead to neurotoxicity $[32,88]$, also at low doses. In Figure 6 , it is shown that the oral ingestion of $\mathrm{TiO}_{2} \mathrm{NPs}$ can affect brain activities via increased oxidative stress, decreased antioxidant enzyme activity, and increased nitric oxide $(\mathrm{NO})$ and ROS release (Figure 6) [89]. $\mathrm{TiO}_{2} \mathrm{NPs}$ thus induced a neurotoxic damage accompanied by the increase in degenerated and apoptotic neurons in cerebral cortex.

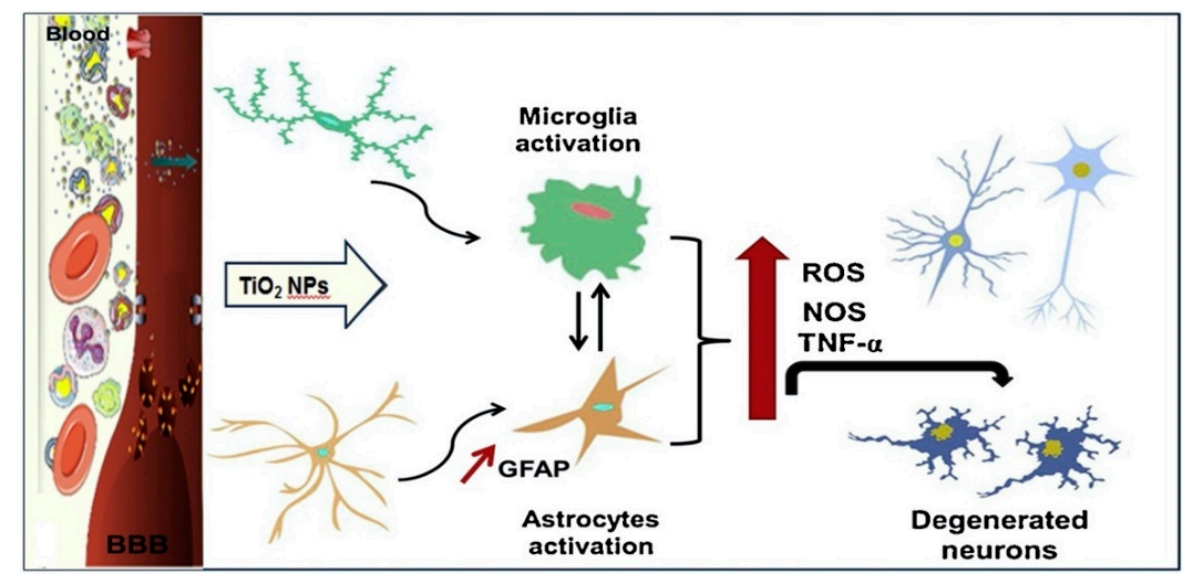

Figure 6. Mechanism of neurotoxicity of $\mathrm{TiO}_{2} \mathrm{NPs}$ in cells. Adapted with permission from [89]. Copyright, 2020 Elsevier B.V.

\subsection{Cardiovascular System}

$\mathrm{TiO}_{2} \mathrm{NPs}$ of $100 \mathrm{~nm}$ significantly reduce mitochondrial 'dehydrogenase activity' in human lymphocyte cells [81]. Mitochondria-mediated apoptosis-based cell death due to DNA damage is induced by $\mathrm{TiO}_{2} \mathrm{NPs}$. When $\mathrm{TiO}_{2} \mathrm{NPs}$ react with hemoglobin, they can weaken red blood cell oxygen transport. Kongseng et al. investigated the cytotoxic effects of $\mathrm{TiO}_{2}$ $\mathrm{NPs}$ on human blood cells, namely peripheral blood mononuclear cells (PBMCs). $\mathrm{TiO}_{2} \mathrm{NPs}$ incubated for $24 \mathrm{~h}$ significantly suppressed cell viability and increased the formation of toxic mediators (Figure 7) [10]. At high $\mathrm{TiO}_{2} \mathrm{NP}$ concentrations $\left(\geq 25 \mu \mathrm{g} \mathrm{mL}^{-1}\right)$, cell apoptosis and the 'proinflammatory cytokine secretion' of PBMCs increased due to oxidative stress caused by ROS. The effect of $\mathrm{TiO}_{2} \mathrm{NPs}$ and bulk material in PBMCs, neopterin formation and tryptophan degradation was studied by Becker et al. [90]. Neopterin production was increased in both unstimulated and stimulated PBMCs, while tryptophan breakdown was suppressed, thus suggesting that the total effect of $\mathrm{TiO}_{2} \mathrm{NPs}$ was strongly pro-inflammatory. Namely, in human body fluids, such response is detected in diseases such as infections and cancer, and is also parallel to the course of atherogenesis and neurodegeneration [90].

In contrast, no significant DNA damage caused to human peripheral blood lymphocytes treated with $\mathrm{TiO}_{2} \mathrm{NPs}$ was observed by an alkaline assay. Only extremely higher concentrations $(100 \mu \mathrm{g})$ can show the genotoxicity of $\mathrm{TiO}_{2}$ [91].

Very little research has been completed on the effect of $\mathrm{TiO}_{2} \mathrm{NPs}$ on the cardiovascular system. Researchers suspect that deposited $\mathrm{TiO}_{2} \mathrm{NPs}$ in the heart may lead to inflammatory responses, system malfunction, and cardiac damage. Depending on the type and duration of exposure, ultrafine $\mathrm{TiO}_{2} \mathrm{NPs}$ could lead to an increase in heart rate, blood pressure, and cardiac muscle damage [32]. 


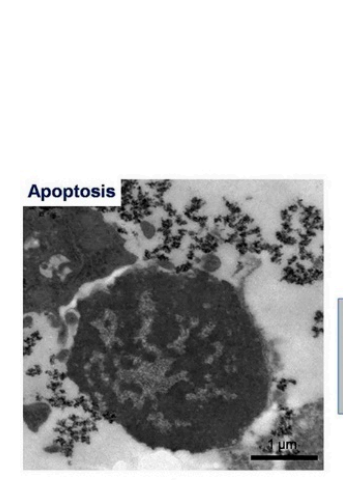

(a)

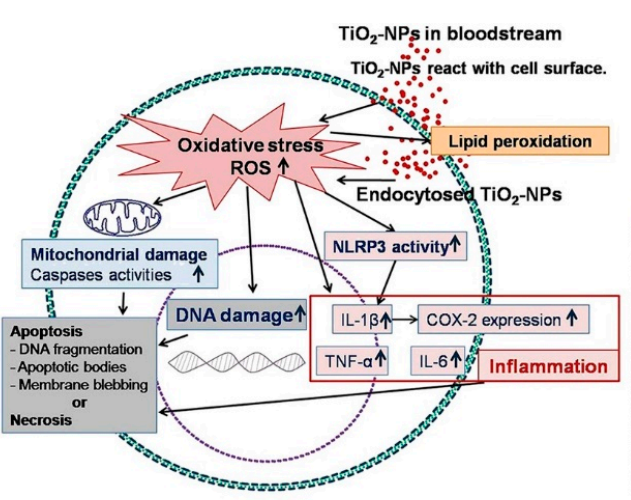

(b)

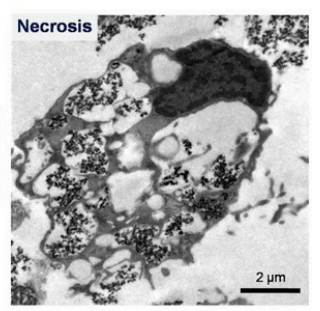

(c)

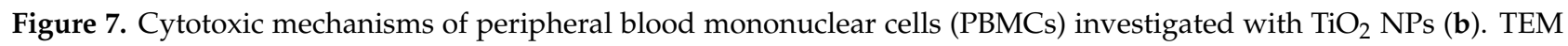
images of apoptosis (a) and necrosis (c) of PBMCs. (COX-2 = cyclooxygenase-2; IL = interleukin; and TNF = tumor necrosis factor). Adapted with permission from [10]. Copyright, 2016 John Wiley \& Sons, Inc.

\subsection{Respiratory System}

The lungs are the main target system of environmental air pollution via $\mathrm{TiO}_{2} \mathrm{NPs}$ [92]. $\mathrm{TiO}_{2}$-induced human lung epithelial cell injury (A549) and alveolar lung inflammation have been reported after inhalation in several studies [93-95]. These phenomena lead to lung dysfunction, as well as irreversible changes to the cells, resulting in fibrosis and tumor development. The lung toxicity and inflammatory effects are related to the properties of $\mathrm{TiO}_{2} \mathrm{NPs}$, such as their size, shape, crystallinity, agglomeration, and surface coating mode [96]. At this point it should be noted that the cytotoxicity of $\mathrm{TiO}_{2} \mathrm{NPs}_{\text {increased in }}$ the following order: amorphous $>$ anatase $>$ anatase/rutile; thus, amorphous $\mathrm{TiO}_{2} \mathrm{NPs}$ possessed greater toxic effect than anatase/rutile $\mathrm{TiO}_{2}$ NPs [95]. Fresegna et al. studied the cellular responses of human alveolar A549 and bronchial BEAS-2B cells to measure the cytotoxic and inflammatory effects of $\mathrm{TiO}_{2}$ NPs in anatase and rutile forms [7]. They found that anatase $\mathrm{TiO}_{2}$ NPs exerted greater cytotoxicity on bronchial cells compared to rutile $\mathrm{TiO}_{2}$ NPs. On the other hand, a higher level of genotoxicity was observed on alveolar and bronchial cells treated with rutile $\mathrm{TiO}_{2}$ compared to anatase $\mathrm{TiO}_{2}$. When $\mathrm{TiO}_{2} \mathrm{NPs}$ are pre-irradiated, they have a greater cytotoxic effect on human lung cells compared to non-irradiated $\mathrm{TiO}_{2}$ NPs [93].

\subsection{Digestive System}

Oral ingestion of $\mathrm{TiO}_{2}$ NPs causes them to enter the digestive system. The blood passes through the stomach and also passes through the liver. Significant concentrations of $\mathrm{TiO}_{2}$ NPs can lead to liver dysfunction, liver cell damage and even liver failure, hepatocyte dysfunction, superficial staining of cytoplasm, and osteoporosis after repeated exposure [40,92]. However, these results, carried out in mice or rats, are controversial, as no toxicity was observed in other studies.

\subsection{Urinary System}

The kidneys are one of the major organs that filter the blood, remove metabolic wastes, control the body's extracellular fluid balance and electrolyte composition, and return the purified blood to the body. Chen et al. demonstrated an association between $\mathrm{TiO}_{2} \mathrm{NPs}_{\text {and }}$ kidney toxicity, suggesting that the kidney may be a major target or organ of exposure to nano- $\mathrm{TiO}_{2}$ via various routes into the body [92]. When cultured embryonic kidney cells were incubated with $\mathrm{TiO}_{2}$ NPs, no significant induction of DNA damage was observed. In this case, only the highest concentration of $\mathrm{TiO}_{2} \mathrm{NPs}$, equivalent to $100 \mu \mathrm{g} / \mathrm{mL}$, elicited a significant genotoxic response, but it was concluded that such a high concentration of $\mathrm{TiO}_{2}$ is not environmentally relevant [91]. However, further studies on renal toxicity in humans due to exposure to $\mathrm{TiO}_{2}$ NPs need to be conducted. 


\subsection{Reproductive System}

Based on the research conducted to date, the toxicity of $\mathrm{TiO}_{2} \mathrm{NPs}$ to the reproductive system such as testes, ovaries, placenta, and fetal tissues in humans is unknown. $\mathrm{TiO}_{2} \mathrm{NPs}$ cause adverse effects on hatching and affect reproduction in zebrafish, as well as pregnancy difficulties such as nanoparticle spread to fetal brain, fetal liver, and placenta in mice [13]. However, the research data are not sufficient to conclude the development of toxicity in the reproductive system of mammals, especially humans.

\subsection{Dermal System}

The penetration of $\mathrm{TiO}_{2} \mathrm{NPs}$ through human skin has not been found in most studies [97-99]. $\mathrm{TiO}_{2} \mathrm{NPs}$ do not cause ROS formation, cellular glutathione content, nor apoptosis when applied to human epidermal (A431) and keratinocytic (HaCaT) skin cells [100,101]. $\mathrm{TiO}_{2}$ NPs cause dermal toxicity only when they pass through healthy or damaged skin after long-term exposure [40]. However, the opposite phenomenon has been observed in several studies. Wright et al. showed that $\mathrm{TiO}_{2} \mathrm{NPs}$ induce superoxide formation, caspase, and cell apoptosis in human keratinocyte cells $(\mathrm{HaCaTs})$ in a dose-dependent manner. This causes cytotoxicity in $\mathrm{HaCaT}$ cells at $10^{-4}-10^{-5} \mathrm{~mol} / \mathrm{L}$ [100]. In fact, human skin is not only exposed to $\mathrm{TiO}_{2} \mathrm{NPs}$, but also external chemicals or stressors, such as UV light [102], which also damage human dermal fibroblasts. The Scientific Committee on Consumer Safety (SCCS) therefore suggested that $\mathrm{TiO}_{2} \mathrm{NPs}$ should not be used in sunscreen formulations with high photocatalytic activity [1].

\section{5. $\mathrm{TiO}_{2} \mathrm{NPs}$ in the Environment (Ecotoxicity)}

Ecotoxicity occurs when biological, physical, and chemical stressors affect living organisms in the ecosystem through altered biochemistry, physiology, and cellular interactions. The ecotoxic adverse effects of $\mathrm{TiO}_{2} \mathrm{NPs}$ have been observed in water, aquatic animals, zebrafish gills, food, and aquatic environments [67]. $\mathrm{TiO}_{2} \mathrm{NPs}$ influence the bacterial colonies in soil, reducing microbial biomass and diversity, thereby having a negative effect by changing the bacterial composition of the ecosystem [103,104]. In addition, terrestrial plants collect $\mathrm{TiO}_{2}$ NPs from the soil and store them in stems, leaves, and fruits, which promotes germination and root expansion $[105,106]$.

\section{1. $\mathrm{TiO}_{2} \mathrm{NPS}$ in the Plant and Soil Environment}

After the use of $\mathrm{TiO}_{2} \mathrm{NPs}$ in various products, this inorganic nanomaterial is mostly abandoned, and a large quantity of $\mathrm{TiO}_{2} \mathrm{NPs}$ is distributed to the environment, reaching the air, soil, water, and living organisms [54]. Figure 8 represents the use, release pathways, distribution, and interaction of $\mathrm{TiO}_{2} \mathrm{NPs}$ to plants and the surrounding environment. $\mathrm{TiO}_{2}$ NPs used in pigments, food additives, and personal care products are released into the soil $(13.8 \%)$, water $(18.5 \%)$, and air $(2.2 \%)$. Therefore, plants come into direct contact with $\mathrm{TiO}_{2}$ NPs through the soil, water, and air.

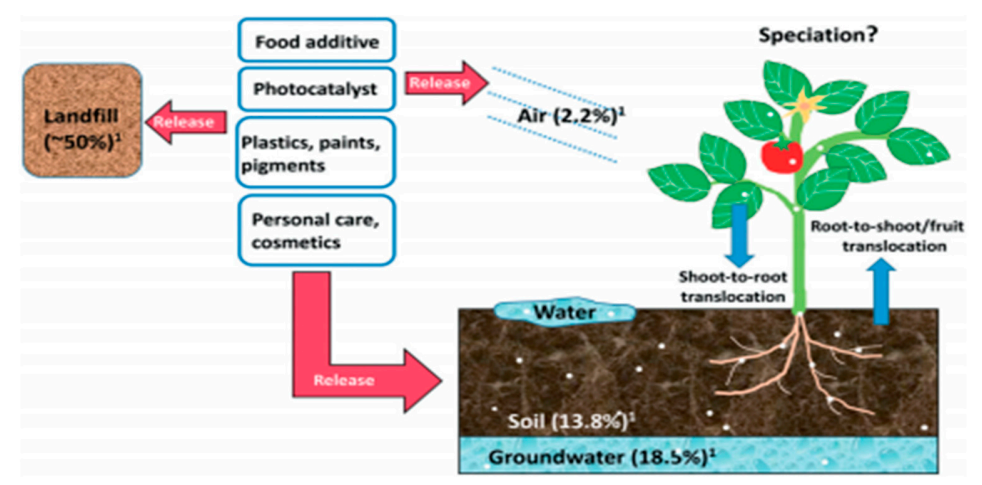

Figure 8. Uses and dispersion of $\mathrm{TiO}_{2} \mathrm{NPs}$ into the environment and interaction with plants. Adapted with permission from [107]. Copyright, 2018 The Royal Society of Chemistry. 
After the entry of $\mathrm{TiO}_{2}$ NPs via several pathways, soil properties-such as soil enzymes, microbial communities, nutritional elements, and $\mathrm{pH}$-affect their behavior, mobility, and bioavailability, thereby determining the fate of $\mathrm{TiO}_{2} \mathrm{NPs}$. The interconnected soil properties/factors, such as soil type, $\mathrm{pH}$, ionic strength, and organic matter, affect the transport of $\mathrm{TiO}_{2} \mathrm{NPs}$ by changing their zeta potential, aggregation, surface charge, and van der Waals force $[108,109]$. The existence of microbes in the soil is vitally important for the decomposition and recycling of organic material. As a result, $\mathrm{TiO}_{2} \mathrm{NPs}$ may alter the microbial population, diversity, and activity by changing the soil properties $[103,110]$. Low concentrations of $\mathrm{TiO}_{2}$ NPs also increase urea activity [111]. On the other hand, at extremely higher concentrations $(1000 \mathrm{mg} / \mathrm{L}), \mathrm{TiO}_{2}$ NPs decrease urea activity $[112,113]$, affect the level of bacterial nitrogen, and reduce catalase, phosphatase, invertase, and peroxidase activities [103]. Reports suggests that $\mathrm{TiO}_{2} \mathrm{NPs}$ also disrupt the gene expression of bacteria, resulting in decreasing nitrogen fixation and methane oxidation, which are essential for the decomposition of proteins and organic pollutants [81].

The interaction between plants and $\mathrm{TiO}_{2} \mathrm{NPs}$ depends on their particle size, crystal phase, and surface coating [107]. Smaller $\mathrm{TiO}_{2}$ NPs (less than $30 \mathrm{~nm}$ ) can enter into plant cells by reducing the size of the pores and the flow of water in corn [114] and wheat [115]. Investigations show that $\mathrm{TiO}_{2} \mathrm{NPs}$ of 12,22 , and $25 \mathrm{~nm}$ can be translocated from the roots to the leaves [115]. The antioxidant stress is interrupted by $\mathrm{TiO}_{2} \mathrm{NPs}$ in duckweed [116] and tomato [117]. $\mathrm{TiO}_{2} \mathrm{NPs}$ also interrupt different parameters in raceme elm [118], onion [119], soybean [120], rice, spinach [121], and parsley [122]. As $\mathrm{TiO}_{2}$ NPs show photocatalytic activity under light irradiation, they can alter photosynthesis, metabolism, and gene expression within plants. Some investigations reported negative effects caused by $\mathrm{TiO}_{2}$ NPs on plant growth, whereas it was concluded that $\mathrm{TiO}_{2} \mathrm{NPs}$ may cause some sensitive plant growth-promoting bacteria to disappear from soil. Accordingly, such impairment of the soil bacterial community composition may further affect ecosystem functioning $[123,124]$.

\section{2. $\mathrm{TiO}_{2} \mathrm{NPs}$ in the Aquatic Environment}

The significantly increased leakage of $\mathrm{TiO}_{2} \mathrm{NPs}$ into surface and marine water environments has a great impact on aquatic ecosystems. The related studies have been mainly concentrated in determining the behavior of $\mathrm{TiO}_{2} \mathrm{NP}$ in marine environments, focusing mostly on marine plankton and benthos, with comparable contribution of papers, i.e., $42.1 \%$ and $44.7 \%$, respectively, as well as in marine fish, with the smallest share of the research, i.e., $13.2 \%$ [125]. As $\mathrm{TiO}_{2} \mathrm{NPs}$ are very reactive, they follow different transformation processes when they are released into the aquatic ecosystem. These transformation processes involve physical (agglomeration, aggregation, and sedimentation) interactions with $\mathrm{TiO}_{2}$ (adsorption), chemical (photochemical) interactions, and biological (biomodification) interactions. The ability of $\mathrm{TiO}_{2} \mathrm{NPs}$ to enter in the aquatic organisms is worrying, as it leads to bioaccumulation in their cellular tissue. Accordingly, NPs negatively affect environmental food webs in three different major ecosystems-freshwater, marine, and terrestrial $[24,126]$. Bearing in mind that mammalians are at the top of the ecological food chain, the ecotoxicity induced by $\mathrm{TiO}_{2} \mathrm{NPs}$ in the environment is easily converted into cytotoxicity in humans (Figure 9) [24].

Phytoplankton is the most dominant factor in marine ecosystems and the food web [127]. The interaction of $\mathrm{TiO}_{2} \mathrm{NPs}$ with marine phytoplankton has therefore been investigated $[127,128]$. In an aquatic environment, $\mathrm{TiO}_{2} \mathrm{NPs}$ may be adsorbed or diffused by the phytoplankton surface. $\mathrm{TiO}_{2} \mathrm{NP}$-mediated $\mathrm{ROS}$ may be diffused by the cell wall when the $\mathrm{TiO}_{2}$-plankton complex generates 'ligand-to-metal charge transfer reactions' [126]. After the aggregation and settling of $\mathrm{TiO}_{2}$ in marine environments, there is still a small fraction of $\mathrm{TiO}_{2} \mathrm{NP}$ nanoparticles in the water column that may be hazardous to the living organisms in that water column. Thus, at higher $\mathrm{TiO}_{2}$ concentrations (>/20 mg/L), $\mathrm{TiO}_{2} \mathrm{NPs}$ can significantly reduce $P$. tricornutum growth, one of the most widely used model organisms used in marine ecotoxicology studies [127]. Miller et al. demonstrated that, at low UV 
levels, $\mathrm{TiO}_{2} \mathrm{NPs}^{\prime}$ photocatalytic activity can induce toxicity in marine phytoplankton [128]. However, in the absence of UV light, no effects were observed.

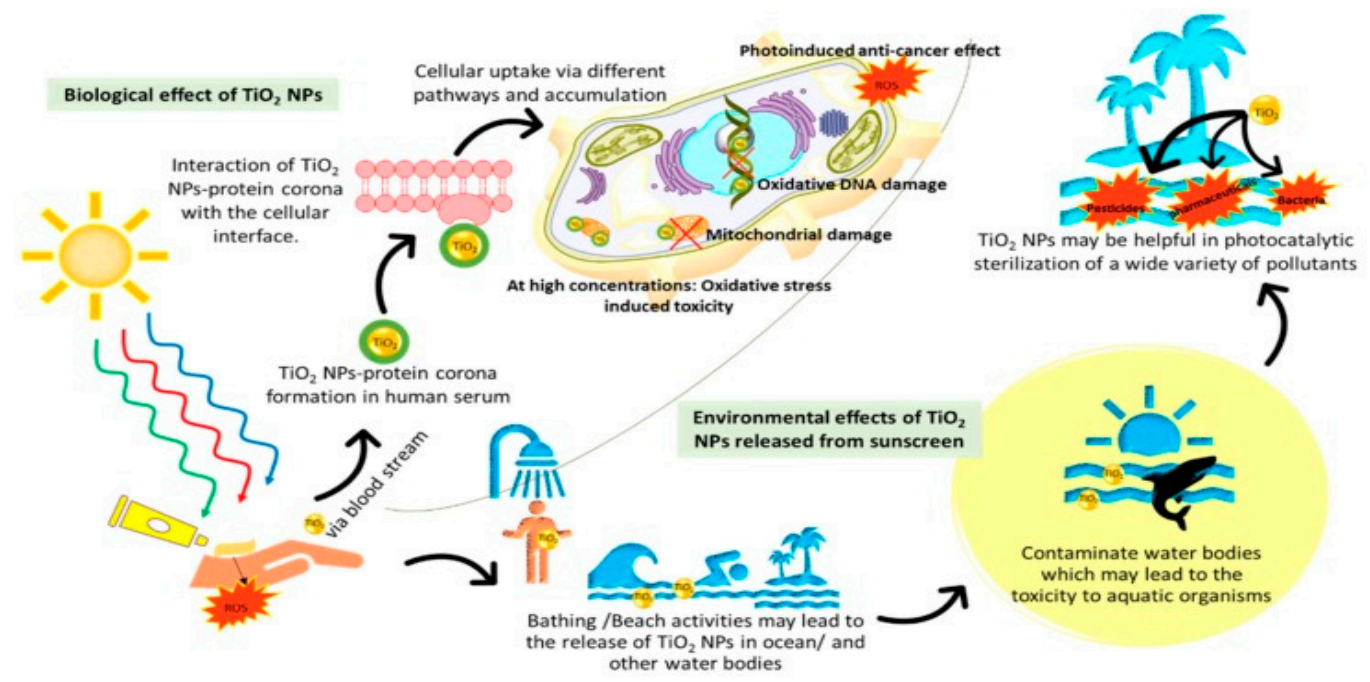

Figure 9. Environmental and biological effects of the $\mathrm{TiO}_{2} \mathrm{NPs}$. Adapted with permission from [24]. Copyright, 2019 MDPI AG.

The toxicity of $\mathrm{TiO}_{2}$ NPs in marine mussels has been investigated in several studies [38,129-134]. Due to the filtrating behavior and bioaccumulation tendency of bivalve mollusks, they accumulate various pollutants, such as microalgae, sediments, bacteria, and contaminants, within their tissues [38]. However, no acute $\mathrm{TiO}_{2} \mathrm{NP}$ toxicity was found in marine abalone at $\mathrm{TiO}_{2} \mathrm{NP}$ concentrations from 0.1 to $10.0 \mathrm{mg} / \mathrm{L}$ [135]. In spite of the absence of toxicity, minor oxidative stress was induced. In another study, the combined effect of $\mathrm{TiO}_{2} \mathrm{NPs}$ and ocean acidification was assessed in mussels [136]. A low pH increases the toxicity of $\mathrm{TiO}_{2} \mathrm{NPs}$ and the impairment of feeding and metabolism was observed in mussels at different $\mathrm{pH}$ and concentrations.

In a different study, the $\mathrm{TiO}_{2} \mathrm{NP}$-fish interaction was examined at different $\mathrm{TiO}_{2} \mathrm{NP}$ concentrations and exposure conditions [137]. $\mathrm{TiO}_{2} \mathrm{NPs}$ of $0,1,10$, and $100 \mathrm{mg} / \mathrm{L}$ were applied to fish for $96 \mathrm{~h}$, resulting in no mortality or sublethal effects. Very few studies associated with $\mathrm{TiO}_{2} \mathrm{NPs}$ have been conducted on fish. As such, more studies need to be conducted in order to understand the potentially cytotoxic effects of $\mathrm{TiO}_{2} \mathrm{NPs}$ on fish.

Moreover, in aquatic environments, $\mathrm{TiO}_{2} \mathrm{NPs}$ can interact with heavy metals $(\mathrm{Cu}, \mathrm{Zn}$, $\mathrm{Cd}$, As, etc.) and toxic organics, resulting in the formation of a harmful environment that can alter the bioavailability of aquatic organisms $[38,138,139]$. If $\mathrm{TiO}_{2} \mathrm{NPs}_{\text {se exposed to }}$ arsenic (As), this can increase arsenic accumulation in aquatic animals and the human food web [139]. However, $\mathrm{TiO}_{2} \mathrm{NP}-\mathrm{Cd}$ interactions do not result in toxicity in Mediterranean mussels [140]. The immunotoxicity, genotoxicity, and neurotoxicity of $\mathrm{TiO}_{2} \mathrm{NPs}_{\text {in }}$ marine living organisms were reported by several researchers, with varying results depending on the particle size, exposure duration, exposure type, and stress factors [38,134,141-145].

\section{Biocompatibility of $\mathrm{TiO}_{2} \mathrm{NPs}$}

The potential toxicity of the $\mathrm{TiO}_{2}$ NPs discussed above does not suggest that they are unsafe for humans or the environment. Depending on the size and shape of the nanoparticles, $\mathrm{TiO}_{2} \mathrm{NPs}$ may be safe, due to their very low toxicity. When it comes to the issue of skin permeation, long-term skin exposure to $\mathrm{TiO}_{2} \mathrm{NPs}$ can be harmful to humans if they overdose, which is almost impossible in everyday life [146]. Biocompatibility refers to the testing of $\mathrm{TiO}_{2} \mathrm{NPs}$ for cytotoxicity, genotoxicity, immunotoxicity, systemic toxicity, hemocompatibility, pyrogenicity, and implantation, evaluated by ISO, ISO/TR 10993-22:2017 via in vitro and in vivo studies [47]. The evaluation of the toxicity and biocompatibility of 
$\mathrm{TiO}_{2}$ NPs is crucial to understanding the deleterious biological responses of the properties of $\mathrm{TiO}_{2} \mathrm{NPs}$, their functionalities, and their contact surfaces (Figure 10a).

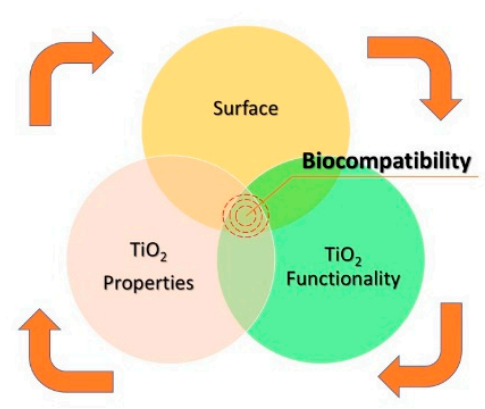

(a)

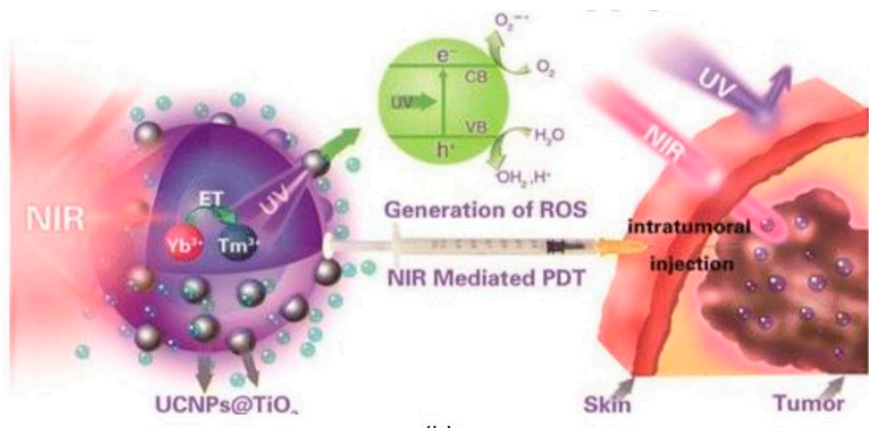

(b)

Figure 10. Biocompatibility of $\mathrm{TiO}_{2} \mathrm{NPs}(\mathbf{a})$ and antitumor treatment by $\mathrm{TiO}_{2} \mathrm{NP}$ ROS formation (b). Adapted with permission from [147]. Copyright, 2015 American Chemical Society.

In terms of the biocompatibility of $\mathrm{TiO}_{2} \mathrm{NPs}$, they are used in drug carrier biosensing, implants, and antibacterial activity [148]. Due to the spherical shape of $\mathrm{TiO}_{2}, \mathrm{TiO}_{2}$-cell interactions, $\mathrm{TiO}_{2}{ }^{\prime} \mathrm{s}$ biocompatibility, excellent drug release properties, and lower toxicity (than $\mathrm{Al}_{2} \mathrm{O}_{3}$ and $\mathrm{SiO}_{2}$ ) [148-150], $\mathrm{TiO}_{2} \mathrm{NPs}$ are used in antitumor treatments (Figure 10b). Due to the cytotoxic $\mathrm{ROS}\left(\mathrm{O}_{2}{ }^{-}, \mathrm{OH}^{-}, \mathrm{H}_{2} \mathrm{O}_{2}\right)$-based interaction between $\mathrm{TiO}_{2} \mathrm{NPs}$ and specific cancer cell membranes, surface-functionalized biocompatible $\mathrm{TiO}_{2} \mathrm{NPs}$ have recently been used for targeted cancer therapy [48]. $\mathrm{TiO}_{2} \mathrm{NPs}$ have also been used in the biomedical field in photothermal therapy (PTT), photodynamic therapy (PDT), and sonodynamic therapy (SDT) for cancer treatment via the targeted, controlled, stimulus-driven delivery and release of cytotoxic anti-cancer agents [148]. Due to their low phototoxicity, biocompatibility and stable structure, $\mathrm{TiO}_{2} \mathrm{NPs}$ have potential applications in phototherapy for the treatment of cancer cells $[49,151]$. When $\mathrm{TiO}_{2} \mathrm{NPs}$ are exposed to light, an oxidative radical (ROS) is generated, which subsequently destroys the cell and cellular components, such as the lipids, proteins, carbohydrates, and nucleic acids in cancer cells [147,152].

Furthermore, several authors have reported that the toxicity of $\mathrm{TiO}_{2} \mathrm{NPs}$ arises due to a 'particle effect' rather than a 'chemical effect' [40]. However, further studies are required to assess the nature, mechanisms, and effects of the toxicity of $\mathrm{TiO}_{2} \mathrm{NPs}_{\mathrm{s}}$ on humans and the surrounding environment.

\section{Risk Management}

\subsection{Risk Following Oral Exposure}

Considering the published studies, $\mathrm{TiO}_{2} \mathrm{NPs}$ have no acute toxic effects after oral exposure. There are insufficient data on the repeated-dose toxicity of $\mathrm{TiO}_{2} \mathrm{NPs}$, so there is not believed to be any significant risk from oral exposure.

\subsection{Risk Following Dermal Exposure}

Based on the current data, short-term dermal exposure to $\mathrm{TiO}_{2} \mathrm{NPs}$ has very little or no toxic effect on healthy skin. Further studies on long-term dermal exposure, as well as on damaged skin, are required in order to evaluate $\mathrm{TiO}_{2} \mathrm{NPs}^{\prime}$ nanotoxicity on the skin [40].

\subsection{Risk Following Inhalation}

It is well established that smaller $\mathrm{TiO}_{2} \mathrm{NPs}$ are more toxic than comparatively coarser $\mathrm{TiO}_{2}$ NPs. Anatase $\mathrm{TiO}_{2}$ is more toxic than rutile $\mathrm{TiO}_{2}$, with its crystalline structure. In terms of inhalation, particle size, surface area, crystalline structure, agglomeration, and exposure, time plays a crucial role in the toxicity of $\mathrm{TiO}_{2} \mathrm{NPs}$. Inhalation is a major problem in workplaces due to high concentrations of $\mathrm{TiO}_{2} \mathrm{NPs}$, as well as the fact that $\mathrm{TiO}_{2} \mathrm{NPs}$ enter the body mainly through respiration. 
The establishment of risk management strategies is therefore crucial (Figure 11), particularly in relation to short-/long-term exposure, as well as the frequency and level of exposure; however, such strategies have not yet been developed. Regulations and legalization for controlling $\mathrm{TiO}_{2}$ NPs and other engineered NPs (ENPs) are unsure, living the interpretation of the scientific data challenging to the government, agencies, industry, and consumers. Recently, suggestions for the safe handling of $\mathrm{TiO}_{2} \mathrm{NPs}$ and other engineered NPs (ENPs) were proposed by Besha et al. [153], highlighting the mitigation approaches to curtail the possible hazard effects of ENPs.

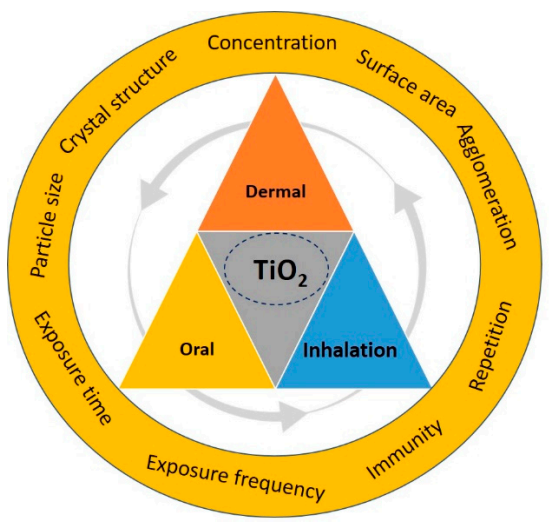

Figure 11. Risk management strategies for human exposure to $\mathrm{TiO}_{2} \mathrm{NPs}$ via different exposure routes.

\section{Conclusions and Future of $\mathrm{TiO}_{2} \mathrm{NPs}$ in Textile Applications}

$\mathrm{TiO}_{2}$ NPs are important photocatalysts that are implemented in various fields of application. The toxicity of $\mathrm{TiO}_{2} \mathrm{NPs}$ to human health and the environment is still controversial. $\mathrm{TiO}_{2}$ NPs are classified as possibly carcinogenic to humans by the International Agency for Research on Cancer (IARC), and as a chemical risk to humans by the Workplace Hazardous Materials Information System (WHMIS) (in group D2A). At lower $\mathrm{TiO}_{2} \mathrm{NP}$ concentrations, recent studies have found that $\mathrm{TiO}_{2} \mathrm{NPs}$ are almost non-toxic, as no remarkable toxicity was observed $[99,154,155]$. However, $\mathrm{TiO}_{2}$ /textile composites, for example, distinguished by remarkable functional properties [156], have no adverse effects on human skin, as superoxide and hydroxyl radicals are not able to damage human cells from the outside as they cannot enter the inner layer of the human skin [155,157]. As $\mathrm{TiO}_{2} / \mathrm{rGO}$-coated cotton fabric is biocompatible, it does not cause cell membrane damage and cell proliferation, as textiles coated with $\mathrm{TiO}_{2}$ NPs do not exhibit cytotoxicity over $24 \mathrm{~h}$ of incubation [158]. With the exception of the other previously mentioned study, to the best of our current knowledge, no experiments have been conducted with $\mathrm{TiO}_{2} \mathrm{NP}$-modified textiles on human skin. Considering the toxicity and ecotoxic pathways described in in vivo and in vitro studies, $\mathrm{TiO}_{2}$ NPs are the safer option when compared to other metal oxide nanomaterials [148]. The nanotoxicity and contradictive biocompatibility of $\mathrm{TiO}_{2} \mathrm{NPs}$ should be further investigated by researchers, whereas studies on long-term or accelerated effects of $\mathrm{TiO}_{2}$ need to be

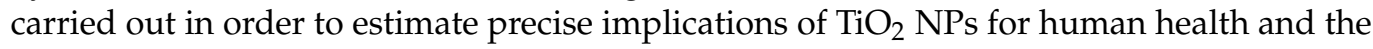
surrounding environment. Therefore, careful consideration should be given to the benefits of $\mathrm{TiO}_{2}$, and the associated potential risks based on its intended use. Moreover, mitigating the toxicity of $\mathrm{TiO}_{2} \mathrm{NPs}$ transferred from consumer products to the environment requires appropriate strategies and regulatory frameworks to protect humans and the environment. Accordingly, the establishment of international standard methods for the exact evaluation of risk-benefit assessments is a prerequisite to allowing the safe use of $\mathrm{TiO}_{2}$-functionalized materials.

Author Contributions: Conceptualization; investigation, and writing-original draft preparation, M.M.R.; writing - review and editing and supervision, P.F.T.; and conceptualization and writingreview and editing, B.T. All authors have read and agreed to the published version of the manuscript. 
Funding: This work was supported by the Slovenian Research Agency (Programs P2-0213 and Infrastructural Centre RIC UL-NTF).

Institutional Review Board Statement: Not applicable.

Informed Consent Statement: Not applicable.

Data Availability Statement: Data sharing not applicable.

Conflicts of Interest: The authors declare no conflict of interest.

\section{References}

1. Zhang, X.; Li, W.; Yang, Z. Toxicology of nanosized titanium dioxide: An update. Arch. Toxicol. 2015, 89, 2207-2217. [CrossRef]

2. Shabbir, S.; Kulyar, M.F.-E.-A.; Bhutta, Z.A.; Boruah, P.; Asif, M. Toxicological Consequences of Titanium Dioxide Nanoparticles $\left(\mathrm{TiO}_{2} \mathrm{NPs}\right)$ and Their Jeopardy to Human Population. BioNanoScience 2021, 11, 621-632. [CrossRef]

3. Scharnberg, A.R.D.A.; de Loreto, A.C.; Wermuth, T.B.; Alves, A.K.; Arcaro, S.; dos Santos, P.A.M.; Rodriguez, A.D.A.L. Porous ceramic supported $\mathrm{TiO}_{2}$ nanoparticles: Enhanced photocatalytic activity for Rhodamine B degradation. Boletín Soc. Española Cerám. Vidrio 2020, 59, 230-238. [CrossRef]

4. Do, H.H.; Nguyen, D.L.T.; Nguyen, X.C.; Le, T.-H.; Nguyen, T.P.; Trinh, Q.T.; Ahn, S.H.; Vo, D.-V.N.; Kim, S.Y.; Van Le, Q. Recent progress in $\mathrm{TiO}_{2}$-based photocatalysts for hydrogen evolution reaction: A review. Arab. J. Chem. 2020, 13, 3653-3671. [CrossRef]

5. Hiremath, V.; Deonikar, V.G.; Kim, H.; Gil Seo, J. Hierarchically assembled porous $\mathrm{TiO}_{2}$ nanoparticles with enhanced photocatalytic activity towards Rhodamine-B degradation. Colloids Surf. A Physicochem. Eng. Asp. 2020, 586, 124199. [CrossRef]

6. Bai, X.; Jia, J.; Du, Y.; Hu, X.; Li, J.; Liu, E.; Fan, J. Multi-level trapped electrons system in enhancing photocatalytic activity of TiO 2 nanosheets for simultaneous reduction of $\mathrm{Cr}$ (VI) and RhB degradation. Appl. Surf. Sci. 2020, 503, 144298. [CrossRef]

7. Fresegna, A.M.; Ursini, C.L.; Ciervo, A.; Maiello, R.; Casciardi, S.; Iavicoli, S.; Cavallo, D. Assessment of the Influence of

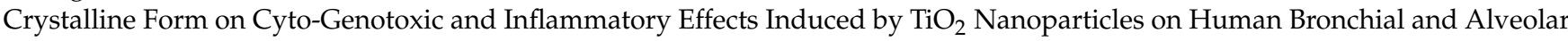
Cells. Nanomaterials 2021, 11, 253. [CrossRef]

8. Alotaibi, A.M.; Williamson, B.A.D.; Sathasivam, S.S.; Kafizas, A.; Alqahtani, M.; Sotelo-Vazquez, C.; Buckeridge, J.; Wu, J.; Nair, S.P.; Scanlon, D.O.; et al. Enhanced Photocatalytic and Antibacterial Ability of Cu-Doped Anatase $\mathrm{TiO}_{2}$ Thin Films: Theory and Experiment. ACS Appl. Mater. Interfaces 2020, 12, 15348-15361. [CrossRef]

9. Zdravkovic, B.; Zdravkovic, T.P.; Zdravkovic, M.; Strukelj, B.; Ferk, P. The influence of nano-TiO 2 on metabolic activity, cytotoxicity and ABCB5 mRNA expression in WM-266-4 human metastatic melanoma cell line. J. Balk. Union Oncol. 2019, 24, 338-346.

10. Kongseng, S.; Yoovathaworn, K.; Wongprasert, K.; Chunhabundit, R.; Sukwong, P.; Pissuwan, D. Cytotoxic and inflammatory responses of $\mathrm{TiO}_{2}$ nanoparticles on human peripheral blood mononuclear cells. J. Appl. Toxicol. 2016, 36, 1364-1373. [CrossRef] [PubMed]

11. Shakeel, M.; Jabeen, F.; Shabbir, S.; Asghar, M.S.; Khan, M.S.; Chaudhry, A.S. Toxicity of Nano-Titanium Dioxide (TiO $2-\mathrm{NP})$ Through Various Routes of Exposure: A Review. Biol. Trace Elem. Res. 2016, 172, 1-36. [CrossRef] [PubMed]

12. Aliakbari, F.; Hosseinali, S.H.; Sarokhalil, Z.K.; Shahpasand, K.; Saboury, A.A.; Akhtari, K.; Falahati, M. Reactive oxygen species generated by titanium oxide nanoparticles stimulate the hemoglobin denaturation and cytotoxicity against human lymphocyte cell. J. Biomol. Struct. Dyn. 2019, 37, 4875-4881. [CrossRef]

13. Dar, G.I.; Saeed, M.; Wu, A. Toxicity of $\mathrm{TiO}_{2}$ Nanoparticles. In $\mathrm{TiO}_{2}$ Nanoparticles: Applications in Nanobiotechnology and Nanomedicine; Wiley: Hoboken, NJ, USA, 2020; pp. 67-103. [CrossRef]

14. Madhubala, V.; Pugazhendhi, A.; Thirunavukarasu, K. Cytotoxic and immunomodulatory effects of the low concentration of titanium dioxide nanoparticles $\left(\mathrm{TiO}_{2} \mathrm{NPs}\right)$ on human cell lines-An in vitro study. Process. Biochem. 2019, 86, 186-195. [CrossRef]

15. Lappas, C.M. The immunomodulatory effects of titanium dioxide and silver nanoparticles. Food Chem. Toxicol. 2015, 85, 78-83. [CrossRef] [PubMed]

16. Kazimirova, A.; El Yamani, N.; Rubio, L.; García-Rodríguez, A.; Barancokova, M.; Marcos, R.; Dusinska, M. Effects of Titanium Dioxide Nanoparticles on the Hprt Gene Mutations in V79 Hamster Cells. Nanomaterials 2020, 10, 465. [CrossRef]

17. Zhu, Y.; Wu, J.; Chen, M.; Liu, X.; Xiong, Y.; Wang, Y.; Feng, T.; Kang, S.; Wang, X. Recent advances in the biotoxicity of metal oxide nanoparticles: Impacts on plants, animals and microorganisms. Chemosphere 2019, 237, 124403. [CrossRef]

18. Attarilar, S.; Yang, J.; Ebrahimi, M.; Wang, Q.; Liu, J.; Tang, Y.; Yang, J. The Toxicity Phenomenon and the Related Occurrence in Metal and Metal Oxide Nanoparticles: A Brief Review from the Biomedical Perspective. Front. Bioeng. Biotechnol. $2020,8,822$. [CrossRef]

19. Tarrahi, R.; Mahjouri, S.; Khataee, A. A review on in vivo and in vitro nanotoxicological studies in plants: A headlight for future targets. Ecotoxicol. Environ. Saf. 2021, 208, 111697. [CrossRef]

20. Hayes, A.W.; Sahu, S.C. Genotoxicity of engineered nanomaterials found in the human environment. Curr. Opin. Toxicol. 2020, 19, 68-71. [CrossRef]

21. Cox, A.; Venkatachalam, P.; Sahi, S.; Sharma, N. Silver and titanium dioxide nanoparticle toxicity in plants: A review of current research. Plant Physiol. Biochem. 2016, 107, 147-163. [CrossRef] 
22. Ling, C.; An, H.; Li, L.; Wang, J.; Lu, T.; Wang, H.; Hu, Y.; Song, G.; Liu, S. Genotoxicity Evaluation of Titanium Dioxide Nanoparticles In Vitro: A Systematic Review of the Literature and Meta-analysis. Biol. Trace Elem. Res. 2021, 199, $2057-2076$. [CrossRef]

23. Markowska-Szczupak, A.; Endo-Kimura, M.; Paszkiewicz, O.; Kowalska, E. Are Titania Photocatalysts and Titanium Implants Safe? Review on the Toxicity of Titanium Compounds. Nanomaterials 2020, 10, 2065. [CrossRef]

24. Sharma, S.; Sharma, R.K.; Gaur, K.; Torres, J.F.C.; Loza-Rosas, S.A.; Torres, A.; Saxena, M.; Julin, M.; Tinoco, A.D. Fueling a Hot Debate on the Application of $\mathrm{TiO}_{2}$ Nanoparticles in Sunscreen. Materials 2019, 12, 2317. [CrossRef]

25. Adler, B.L.; DeLeo, V.A. Sunscreen Safety: A Review of Recent Studies on Humans and the Environment. Curr. Dermatol. Rep. 2020, 9, 1-9. [CrossRef]

26. Akın, N.; Danacı, H.M. An investigation into the architectural use of nanotechnology in the context of the titanium dioxide. Environ. Sci. Pollut. Res. 2021, 93, 1-7. [CrossRef]

27. Chen, Z.; Han, S.; Zhou, S.; Feng, H.; Liu, Y.; Jia, G. Review of health safety aspects of titanium dioxide nanoparticles in food application. NanoImpact 2020, 18, 100224. [CrossRef]

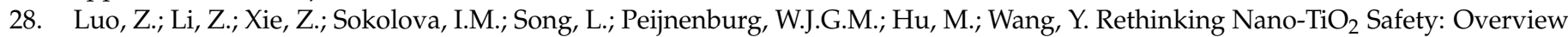
of Toxic Effects in Humans and Aquatic Animals. Small 2020, 16, 2002019. [CrossRef] [PubMed]

29. Tibau, A.V.; Grube, B.D.; Velez, B.J.; Vega, V.M.; Mutter, J. Titanium exposure and human health. Oral Sci. Int. 2019, 16, 15-24. [CrossRef]

30. Bischoff, N.S.; De Kok, T.M.; Sijm, D.T.; Van Breda, S.G.; Briedé, J.J.; Castenmiller, J.J.; Opperhuizen, A.; Chirino, Y.I.; Dirven, H.; Gott, D.; et al. Possible Adverse Effects of Food Additive E171 (Titanium Dioxide) Related to Particle Specific Human Toxicity, Including the Immune System. Int. J. Mol. Sci. 2020, 22, 207. [CrossRef] [PubMed]

31. Cao, Y.; Gong, Y.; Liao, W.; Luo, Y.; Wu, C.; Wang, M.; Yang, Q. A review of cardiovascular toxicity of $\mathrm{TiO}_{2}$, $\mathrm{ZnO}$ and $\mathrm{Ag}$ nanoparticles (NPs). BioMetals 2018, 31, 457-476. [CrossRef] [PubMed]

32. Baranowska-Wójcik, E.; Szwajgier, D.; Oleszczuk, P.; Winiarska-Mieczan, A. Effects of Titanium Dioxide Nanoparticles Exposure on Human Health-A Review. Biol. Trace Elem. Res. 2020, 193, 118-129. [CrossRef] [PubMed]

33. Praphawatvet, T.; Peters, J.I.; Williams, R.O. Inhaled nanoparticles-An updated review. Int. J. Pharm. 2020, 587, 119671. [CrossRef] [PubMed]

34. Kabir, E.; Kumar, V.; Kim, K.-H.; Yip, A.C.; Sohn, J. Environmental impacts of nanomaterials. J. Environ. Manag. 2018, $225,261-271$. [CrossRef] [PubMed]

35. Martínez, G.; Merinero, M.; Pérez-Aranda, M.; Pérez-Soriano, E.; Ortiz, T.; Villamor, E.; Begines, B.; Alcudia, A. Environmental Impact of Nanoparticles' Application as an Emerging Technology: A Review. Materials 2020, 14, 166. [CrossRef] [PubMed]

36. Heilgeist, S.; Sekine, R.; Sahin, O.; Stewart, R. Finding Nano: Challenges Involved in Monitoring the Presence and Fate of Engineered Titanium Dioxide Nanoparticles in Aquatic Environments. Water 2021, 13, 734. [CrossRef]

37. Lehutso, R.; Tancu, Y.; Maity, A.; Thwala, M. Aquatic toxicity of transformed and product-released engineered nanomaterials: An overview of the current state of knowledge. Process. Saf. Environ. Prot. 2020, 138, 39-56. [CrossRef]

38. Abdel-Latif, H.M.; Dawood, M.; Menanteau-Ledouble, S.; El-Matbouli, M. Environmental transformation of $n-T_{2} \mathrm{O}_{2}$ in the aquatic systems and their ecotoxicity in bivalve mollusks: A systematic review. Ecotoxicol. Environ. Saf. 2020, 200, 110776. [CrossRef]

39. Yang, W.; Peters, J.I.; Williams, R.O., III. Inhaled nanoparticles-A current review. Int. J. Pharm. 2008, 356, 239-247. [CrossRef]

40. Christensen, F.M.; Johnston, H.J.; Stone, V.; Aitken, R.J.; Hankin, S.; Peters, S.; Aschberger, K. Nano-TiO $\mathrm{N}_{2}-\mathrm{Feasibility} \mathrm{and}$ challenges for human health risk assessment based on open literature. Nanotoxicology 2010, 5, 110-124. [CrossRef]

41. Kreyling, W.G.; Holzwarth, U.; Schleh, C.; Kozempel, J.; Wenk, A.; Haberl, N.; Hirn, S.; Schäffler, M.; Lipka, J.; Semmler-Behnke, M.; et al. Quantitative biokinetics of titanium dioxide nanoparticles after oral application in rats: Part 2. Nanotoxicology 2017, 11, 443-453. [CrossRef]

42. Heyder, J.; Gebhart, J.; Rudolf, G.; Schiller, C.; Stahlhofen, W. Deposition of particles in the human respiratory tract in the size range $0.005-15 \mu \mathrm{m}$. J. Aerosol Sci. 1986, 17, 811-825. [CrossRef]

43. Hongbo, S.; Magaye, R.; Castranova, V.; Zhao, J. Titanium dioxide nanoparticles: A review of current toxicological data. Part. Fibre Toxicol. 2013, 10, 1-33. [CrossRef]

44. Kermanizadeh, A.; Balharry, D.; Wallin, H.; Loft, S.; Møller, P. Nanomaterial translocation-the biokinetics, tissue accumulation, toxicity and fate of materials in secondary organs-A review. Crit. Rev. Toxicol. 2015, 45, 837-872. [CrossRef] [PubMed]

45. Ren, W.; Yan, Y.; Zeng, L.; Shi, Z.; Gong, A.; Schaaf, P.; Wang, D.; Zhao, J.; Zou, B.; Yu, H.; et al. A Near Infrared Light Triggered Hydrogenated Black $\mathrm{TiO}_{2}$ for Cancer Photothermal Therapy. Adv. Health Mater. 2015, 4, 1526-1536. [CrossRef] [PubMed]

46. Ren, W.; Iqbal, M.Z.; Zeng, L.; Chen, T.; Pan, Y.; Zhao, J.; Yin, H.; Zhang, L.; Zhang, J.; Li, A.; et al. Black TiO 2 based core-shell nanocomposites as doxorubicin carriers for thermal imaging guided synergistic therapy of breast cancer. Nanoscale 2017, 9, 11195-11204. [CrossRef] [PubMed]

47. Kyriakides, T.R.; Raj, A.; Tseng, T.H.; Xiao, H.; Nguyen, R.; Mohammed, F.S.; Halder, S.S.; Xu, M.; Wu, M.J.; Bao, S.; et al. Biocompatibility of nanomaterials and their immunological properties. Biomed. Mater. 2021, 16, 042005. [CrossRef]

48. Thevenot, P.; Cho, J.; Wavhal, D.; Timmons, R.B.; Tang, L. Surface chemistry influences cancer killing effect of $\mathrm{TiO}_{2}$ nanoparticles. Nanomed. Nanotechnol. Biol. Med. 2008, 4, 226-236. [CrossRef] [PubMed]

49. Jukapli, N.M.; Bagheri, S. Recent developments on titania nanoparticle as photocatalytic cancer cells treatment. J. Photochem. Photobiol. B Biol. 2016, 163, 421-430. [CrossRef] 
50. Hou, J.; Wang, L.; Wang, C.; Zhang, S.; Liu, H.; Li, S.; Wang, X. Toxicity and mechanisms of action of titanium dioxide nanoparticles in living organisms. J. Environ. Sci. 2019, 75, 40-53. [CrossRef]

51. Scandalios, J.G. Oxidative stress responses-What have genome-scale studies taught us? Genome Biol. 2002, 3, 1-6. [CrossRef]

52. Bhattacharya, K.; Davoren, M.; Boertz, J.; Schins, R.P.; Hoffmann, E.; Dopp, E. Titanium dioxide nanoparticles induce oxidative stress and DNA-adduct formation but not DNA-breakage in human lung cells. Part. Fibre Toxicol. 2009, 6, 17. [CrossRef]

53. Vevers, W.; Jha, A.N. Genotoxic and cytotoxic potential of titanium dioxide $\left(\mathrm{TiO}_{2}\right)$ nanoparticles on fish cells in vitro. Ecotoxicology 2008, 17, 410-420. [CrossRef] [PubMed]

54. Xia, T.; Kovochich, M.; Brant, J.; Hotze, M.; Sempf, J.; Oberley, T.; Sioutas, C.; Yeh, J.I.; Wiesner, M.R.; Nel, A.E. Comparison of the Abilities of Ambient and Manufactured Nanoparticles to Induce Cellular Toxicity According to an Oxidative Stress Paradigm. Nano Lett. 2006, 6, 1794-1807. [CrossRef] [PubMed]

55. Aderem, A.; Underhill, D. Mechanisms of Phagocytosis in Macrophages. Annu. Rev. Immunol. 1999, 17, 593-623. [CrossRef]

56. Ghosh, M.; Bandyopadhyay, M.; Mukherjee, A. Genotoxicity of titanium dioxide $\left(\mathrm{TiO}_{2}\right)$ nanoparticles at two trophic levels: Plant and human lymphocytes. Chemosphere 2010, 81, 1253-1262. [CrossRef]

57. Morishige, T.; Yoshioka, Y.; Tanabe, A.; Yao, X.; Tsunoda, S.-I.; Tsutsumi, Y.; Mukai, Y.; Okada, N.; Nakagawa, S. Titanium dioxide induces different levels of IL-1 $\beta$ production dependent on its particle characteristics through caspase- 1 activation mediated by reactive oxygen species and cathepsin B. Biochem. Biophys. Res. Commun. 2010, 392, 160-165. [CrossRef]

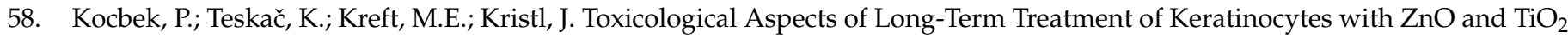
Nanoparticles. Small 2010, 6, 1908-1917. [CrossRef] [PubMed]

59. Sha, B.; Gao, W.; Wang, S.; Gou, X.; Li, W.; Liang, X.; Qu, Z.; Xu, F.; Lu, T.J. Oxidative stress increased hepatotoxicity induced by nano-titanium dioxide in BRL-3A cells and Sprague-Dawley rats. J. Appl. Toxicol. 2013, 34, 345-356. [CrossRef] [PubMed]

60. Rothen-Rutishauser, B.M.; Schürch, S.; Haenni, B.; Kapp, N.; Gehr, P. Interaction of Fine Particles and Nanoparticles with Red Blood Cells Visualized with Advanced Microscopic Techniques. Environ. Sci. Technol. 2006, 40, 4353-4359. [CrossRef] [PubMed]

61. Di Virgilio, A.L.; Reigosa, M.; de Mele, M.F.L. Response of UMR 106 cells exposed to titanium oxide and aluminum oxide nanoparticles. J. Biomed. Mater. Res. Part A 2010, 92, 80-86. [CrossRef] [PubMed]

62. Carriere, M.; Arnal, M.-E.; Douki, T. $\mathrm{TiO}_{2}$ genotoxicity: An update of the results published over the last six years. Mutat. Res. Toxicol. Environ. Mutagen. 2020, 854-855, 503198. [CrossRef]

63. Kansara, K.; Kumar, A.; Karakoti, A.S. Combination of humic acid and clay reduce the ecotoxic effect of TiO $\mathrm{NPs} \mathrm{N}^{\mathrm{A}}$ combined physico-chemical and genetic study using zebrafish embryo. Sci. Total Environ. 2020, 698, 134133. [CrossRef]

64. Li, N.; Ma, L.; Wang, J.; Zheng, L.; Liu, J.; Duan, Y.; Liu, H.; Zhao, X.; Wang, S.; Wang, H.; et al. Interaction Between Nano-Anatase $\mathrm{TiO}_{2}$ and Liver DNA from Mice In Vivo. Nanoscale Res. Lett. 2010, 5, 108-115. [CrossRef]

65. Kim, K.-P.; Lee, S.-J.; Kim, D.-H.; Hwang, D.-K. Effect of anodic aluminum oxide template imprinting on $\mathrm{TiO}_{2}$ blocking layer of flexible dye-sensitized solar cell. J. Nanosci. Nanotechnol. 2013, 13, 1888-1890. [CrossRef]

66. Aslantürk, Ö.S. In Vitro Cytotoxicity and Cell Viability Assays: Principles, Advantages, and Disadvantages. In Genotoxicity A Predictable Risk to Our Actual World; InTech: Rijeka, Croatia, 2018.

67. Sha, B.; Gao, W.; Wang, S.; Xu, F.; Lu, T. Cytotoxicity of titanium dioxide nanoparticles differs in four liver cells from human and rat. Compos. Part B Eng. 2011, 42, 2136-2144. [CrossRef]

68. Sha, B.; Gao, W.; Cui, X.; Wang, L.; Xu, F. The potential health challenges of $\mathrm{TiO}_{2}$ nanomaterials. J. Appl. Toxicol. 2015, 35, 1086-1101. [CrossRef] [PubMed]

69. Mohammadinejad, R.; Moosavi, M.A.; Tavakol, S.; Vardar, D.Ö.; Hosseini, A.; Rahmati, M.; Dini, L.; Hussain, S.; Mandegary, A.; Klionsky, D.J. Necrotic, apoptotic and autophagic cell fates triggered by nanoparticles. Autophagy 2019, 15, 4-33. [CrossRef]

70. Wang, J.; Chen, C.; Liu, Y.; Jiao, F.; Li, W.; Lao, F.; Li, Y.-F.; Li, B.; Ge, C.; Zhou, G. Potential neurological lesion after nasal instillation of $\mathrm{TiO}_{2}$ nanoparticles in the anatase and rutile crystal phases. Toxicol. Lett. 2008, 183, 72-80. [CrossRef] [PubMed]

71. Kang, J.L.; Moon, C.; Lee, H.S.; Lee, H.W.; Park, E.-M.; Kim, H.S.; Castranova, V. Comparison of the Biological Activity between Ultrafine and Fine Titanium Dioxide Particles in RAW 264.7 Cells Associated with Oxidative Stress. J. Toxicol. Environ. Health Part A 2008, 71, 478-485. [CrossRef] [PubMed]

72. Chen, T.; Yan, J.; Li, Y. Genotoxicity of titanium dioxide nanoparticles. J. Food Drug Anal. 2014, 22, 95-104. [CrossRef]

73. Sv, R. Genotoxicity: Mechanisms, Testing Guidelines and Methods. Glob. J. Pharm. Pharm. Sci. 2017, 1, 133-138. [CrossRef]

74. Yazdi, A.S.; Guarda, G.; Riteau, N.; Drexler, S.K.; Tardivel, A.; Couillin, I.; Tschopp, J. Nanoparticles activate the NLR pyrin domain containing 3 (Nlrp3) inflammasome and cause pulmonary inflammation through release of IL-1 $\alpha$ and IL-1 $\beta$. Proc. Natl. Acad. Sci. USA 2010, 107, 19449-19454. [CrossRef] [PubMed]

75. Long, T.C.; Tajuba, J.; Sama, P.; Saleh, N.; Swartz, C.; Parker, J.; Hester, S.; Lowry, G.V.; Veronesi, B. Nanosize Titanium Dioxide Stimulates Reactive Oxygen Species in Brain Microglia and Damages Neurons in Vitro. Environ. Health Perspect. 2007, 115, 1631-1637. [CrossRef] [PubMed]

76. Jugan, M.-L.; Barillet, S.; Simon-Deckers, A.; Herlin-Boime, N.; Sauvaigo, S.; Douki, T.; Carriere, M. Titanium dioxide nanoparticles exhibit genotoxicity and impair DNA repair activity in A549 cells. Nanotoxicology 2011, 6, 501-513. [CrossRef] [PubMed]

77. Saquib, Q.; Al-Khedhairy, A.A.; Siddiqui, M.A.; Abou-Tarboush, F.M.; Azam, A.; Musarrat, J. Titanium dioxide nanoparticles induced cytotoxicity, oxidative stress and DNA damage in human amnion epithelial (WISH) cells. Toxicol. Vitr. 2012, 26, 351-361. [CrossRef] [PubMed] 
78. Trouiller, B.; Reliene, R.; Westbrook, A.; Solaimani, P.; Schiestl, R.H. Titanium Dioxide Nanoparticles Induce DNA Damage and Genetic Instability in vivo in Mice. Cancer Res. 2009, 69, 8784-8789. [CrossRef]

79. Falck, G.C.M.; Lindberg, H.K.; Suhonen, S.; Vippola, M.; Vanhala, E.; Catalán, J.; Savolainen, K.; Norppa, H. Genotoxic effects of nanosized and fine $\mathrm{TiO}_{2}$. Hum. Exp. Toxicol. 2009, 28, 339-352. [CrossRef]

80. Suzuki, T.; Miura, N.; Hojo, R.; Yanagiba, Y.; Suda, M.; Hasegawa, T.; Miyagawa, M.; Wang, R.-S. Genotoxicity assessment of titanium dioxide nanoparticle accumulation of 90 days in the liver of gpt delta transgenic mice. Genes Environ. 2020, 42, 1-6. [CrossRef]

81. Ghosh, M.; Chakraborty, A.; Mukherjee, A. Cytotoxic, genotoxic and the hemolytic effect of titanium dioxide $\left(\mathrm{TiO}_{2}\right)$ nanoparticles on human erythrocyte and lymphocyte cells in vitro. J. Appl. Toxicol. 2013, 33, 1097-1110. [CrossRef]

82. Brandão, F.; Fernández-Bertólez, N.; Rosário, F.; Bessa, M.J.; Fraga, S.; Pásaro, E.; Teixeira, J.P.; Laffon, B.; Valdiglesias, V.; Costa, C. Genotoxicity of $\mathrm{TiO}_{2}$ Nanoparticles in Four Different Human Cell Lines (A549, HEPG2, A172 and SH-SY5Y). Nanomaterials 2020, 10, 412. [CrossRef] [PubMed]

83. Luo, Y.-H.; Chang, L.W.; Lin, P. Metal-Based Nanoparticles and the Immune System: Activation, Inflammation, and Potential Applications. BioMed Res. Int. 2015, 2015, 1-12. [CrossRef]

84. Dhupal, M.; Oh, J.-M.; Tripathy, D.R.; Kim, S.-K.; Koh, S.B.; Park, K.-S. Immunotoxicity of titanium dioxide nanoparticles via simultaneous induction of apoptosis and multiple toll-like receptors signaling through ROS-dependent SAPK/JNK and p38 MAPK activation. Int. J. Nanomed. 2018, 13, 6735-6750. [CrossRef]

85. Peters, A.; Veronesi, B.; Calderón-Garcidueñas, L.; Gehr, P.; Chen, L.C.; Geiser, M.; Reed, W.; Rothen-Rutishauser, B.; Schürch, S.; Schulz, H. Translocation and potential neurological effects of fine and ultrafine particles a critical update. Part. Fibre Toxicol. 2006, 3, 13. [CrossRef]

86. Song, B.; Liu, J.; Feng, X.; Wei, L.; Shao, L. A review on potential neurotoxicity of titanium dioxide nanoparticles. Nanoscale Res. Lett. 2015, 10, 1-17. [CrossRef]

87. Li, X.; Xu, S.; Zhang, Z.; Schluesener, H.J. Apoptosis induced by titanium dioxide nanoparticles in cultured murine microglia N9 cells. Chin. Sci. Bull. 2009, 54, 3830-3836. [CrossRef]

88. Huerta-García, E.; Pérez-Arizti, J.A.; Márquez-Ramírez, S.G.; Delgado-Buenrostro, N.L.; Chirino, Y.I.; Iglesias, G.G.; López-Marure, R. Titanium dioxide nanoparticles induce strong oxidative stress and mitochondrial damage in glial cells. Free. Radic. Biol. Med. 2014, 73, 84-94. [CrossRef]

89. Grissa, I.; ElGhoul, J.; Mrimi, R.; El Mir, L.; Ben Cheikh, H.; Horcajada, P. In deep evaluation of the neurotoxicity of orally administered $\mathrm{TiO}_{2}$ nanoparticles. Brain Res. Bull. 2020, 155, 119-128. [CrossRef] [PubMed]

90. Becker, K.; Schroecksnadel, S.; Geisler, S.; Carriere, M.; Gostner, J.; Schennach, H.; Herlin, N.; Fuchs, D. TiO 2 nanoparticles and bulk material stimulate human peripheral blood mononuclear cells. Food Chem. Toxicol. 2014, 65, 63-69. [CrossRef] [PubMed]

91. Demir, E.; Burgucu, D.; Turna, F.; Aksakal, S.; Kaya, B. Determination of $\mathrm{TiO}_{2}, \mathrm{ZrO}_{2}$, and $\mathrm{Al}_{2} \mathrm{O}_{3}$ Nanoparticles on Genotoxic Responses in Human Peripheral Blood Lymphocytes and Cultured Embyronic Kidney Cells. J. Toxicol. Environ. Health Part A 2013, 76, 990-1002. [CrossRef]

92. Chang, X.; Zhang, Y.; Tang, M.; Wang, B. Health effects of exposure to nano- $\mathrm{TiO}_{2}$ : A meta-analysis of experimental studies. Nanoscale Res. Lett. 2013, 8, 51. [CrossRef] [PubMed]

93. Kose, O.; Tomatis, M.; Turci, F.; Belblidia, N.-B.; Hochepied, J.-F.; Pourchez, J.; Forest, V. Short Preirradiation of TiO $2 \mathrm{Nanoparticles}^{2}$ Increases Cytotoxicity on Human Lung Coculture System. Chem. Res. Toxicol. 2021, 34, 733-742. [CrossRef] [PubMed]

94. Kim, I.-S.; Baek, M.; Choi, S.-J. Comparative cytotoxicity of $\mathrm{Al}_{2} \mathrm{O}_{3}, \mathrm{CeO}_{2}, \mathrm{TiO}_{2}$ and $\mathrm{ZnO}$ nanoparticles to human lung cells. J. Nanosci. Nanotechnol. 2010, 10, 3453-3458. [CrossRef] [PubMed]

95. Hsiao, I.-L.; Huang, Y.-J. Effects of various physicochemical characteristics on the toxicities of $\mathrm{ZnO}$ and $\mathrm{TiO}_{2}$ nanoparticles toward human lung epithelial cells. Sci. Total Environ. 2011, 409, 1219-1228. [CrossRef] [PubMed]

96. Wang, J.; Fan, Y. Lung Injury Induced by $\mathrm{TiO}_{2}$ Nanoparticles Depends on Their Structural Features: Size, Shape, Crystal Phases, and Surface Coating. Int. J. Mol. Sci. 2014, 15, 22258-22278. [CrossRef]

97. Crosera, M.; Prodi, A.; Mauro, M.; Pelin, M.; Florio, C.; Bellomo, F.; Adami, G.; Apostoli, P.; De Palma, G.; Bovenzi, M.; et al. Titanium Dioxide Nanoparticle Penetration into the Skin and Effects on HaCaT Cells. Int. J. Environ. Res. Public Health 2015, 12, 9282-9297. [CrossRef]

98. Xie, G.; Lu, W.; Lu, D. Penetration of Titanium Dioxide Nanoparticles through Slightly Damaged Skin in Vitro and in vivo. J. Appl. Biomater. Funct. Mater. 2015, 13, 356-361. [CrossRef] [PubMed]

99. Geppert, M.; Schwarz, A.; Stangassinger, L.M.; Wenger, S.; Wienerroither, L.M.; Ess, S.; Duschl, A.; Himly, M. Interactions of TiO 2 Nanoparticles with Ingredients from Modern Lifestyle Products and Their Effects on Human Skin Cells. Chem. Res. Toxicol. 2020, 33, 1215-1225. [CrossRef]

100. Wright, C.; Iyer, A.K.V.; Wang, L.; Wu, N.; Yakisich, J.S.; Rojanasakul, Y.; Azad, N. Effects of titanium dioxide nanoparticles on human keratinocytes. Drug Chem. Toxicol. 2016, 40, 90-100. [CrossRef]

101. Shukla, R.; Sharma, V.; Pandey, A.K.; Singh, S.; Sultana, S.; Dhawan, A. ROS-mediated genotoxicity induced by titanium dioxide nanoparticles in human epidermal cells. Toxicol. Vitr. 2011, 25, 231-241. [CrossRef]

102. Smijs, T.G.; Pavel, S. Titanium dioxide and zinc oxide nanoparticles in sunscreens: Focus on their safety and effectiveness. Nanotechnol. Sci. Appl. 2011, 4, 95. [CrossRef] 
103. Ge, Y.; Priester, J.H.; Van De Werfhorst, L.C.; Schimel, J.P.; Holden, P.A. Potential Mechanisms and Environmental Controls of $\mathrm{TiO}_{2}$ Nanoparticle Effects on Soil Bacterial Communities. Environ. Sci. Technol. 2013, 47, 14411-14417. [CrossRef]

104. Binh, C.T.T.; Tong, T.; Gaillard, J.-F.; Gray, K.A.; Kelly, J.J. Common freshwater bacteria vary in their responses to short-term exposure to nano-TiO 2 . Environ. Toxicol. Chem. 2013, 33, 317-327. [CrossRef]

105. Song, U.; Jun, H.; Waldman, B.; Roh, J.; Kim, Y.; Yi, J.; Lee, E.J. Functional analyses of nanoparticle toxicity: A comparative study of the effects of $\mathrm{TiO}_{2}$ and Ag on tomatoes (Lycopersicon esculentum). Ecotoxicol. Environ. Saf. 2013, 93, 60-67. [CrossRef] [PubMed]

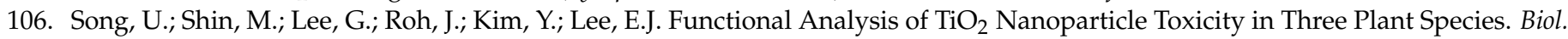
Trace Elem. Res. 2013, 155, 93-103. [CrossRef] [PubMed]

107. Tan, W.; Peralta-Videa, J.R.; Gardea-Torresdey, J.L. Interaction of titanium dioxide nanoparticles with soil components and plants: Current knowledge and future research needs-A critical review. Environ. Sci. Nano 2018, 5, 257-278. [CrossRef]

108. Lin, D.; Tian, X.; Wu, F.; Xing, B. Fate and Transport of Engineered Nanomaterials in the Environment. J. Environ. Qual. 2010, 39, 1896-1908. [CrossRef]

109. Pachapur, V.L.; Larios, A.D.; Cledón, M.; Brar, S.K.; Verma, M.; Surampalli, R. Behavior and characterization of titanium dioxide and silver nanoparticles in soils. Sci. Total Environ. 2016, 563-564, 933-943. [CrossRef]

110. Cai, L.; Tong, M.; Wang, X.; Kim, H. Influence of Clay Particles on the Transport and Retention of Titanium Dioxide Nanoparticles in Quartz Sand. Environ. Sci. Technol. 2014, 48, 7323-7332. [CrossRef]

111. Du, W.; Sun, Y.; Ji, R.; Zhu, J.; Wu, J.; Guo, $\mathrm{H}_{\text {. }} \mathrm{TiO}_{2}$ and $\mathrm{ZnO}$ nanoparticles negatively affect wheat growth and soil enzyme activities in agricultural soil. J. Environ. Monit. 2011, 13, 822-828. [CrossRef]

112. You, T.; Liu, D.; Chen, J.; Yang, Z.; Dou, R.; Gao, X.; Wang, L. Effects of metal oxide nanoparticles on soil enzyme activities and bacterial communities in two different soil types. J. Soils Sediments 2018, 18, 211-221. [CrossRef]

113. Chai, H.; Yao, J.; Sun, J.; Zhang, C.; Liu, W.; Zhu, M.; Ceccanti, B. The Effect of Metal Oxide Nanoparticles on Functional Bacteria and Metabolic Profiles in Agricultural Soil. Bull. Environ. Contam. Toxicol. 2015, 94, 490-495. [CrossRef]

114. Asli, S.; Neumann, P.M. Colloidal suspensions of clay or titanium dioxide nanoparticles can inhibit leaf growth and transpiration via physical effects on root water transport. Plant Cell Environ. 2009, 32, 577-584. [CrossRef]

115. Larue, C.; Laurette, J.; Herlin-Boime, N.; Khodja, H.; Fayard, B.; Flank, A.-M.; Brisset, F.; Carriere, M. Accumulation, translocation and impact of $\mathrm{TiO}_{2}$ nanoparticles in wheat (Triticum aestivum spp.): Influence of diameter and crystal phase. Sci. Total Environ. 2012, 431, 197-208. [CrossRef]

116. Song, G.; Gao, Y.; Wu, H.; Hou, W.; Zhang, C.; Ma, H. Physiological effect of anatase $\mathrm{TiO}_{2}$ nanoparticles on Lemna minor. Environ. Toxicol. Chem. 2012, 31, 2147-2152. [CrossRef]

117. Morteza, E.; Moaveni, P.; Farahani, H.A.; Kiyani, M. Study of photosynthetic pigments changes of maize (Zea mays L.) under nano $\mathrm{TiO}_{2}$ spraying at various growth stages. SpringerPlus 2013, 2, 247. [CrossRef] [PubMed]

118. Gao, J.; Xu, G.; Qian, H.; Liu, P.; Zhao, P.; Hu, Y. Effects of nano- $\mathrm{TiO}_{2}$ on photosynthetic characteristics of Ulmus elongata seedlings. Environ. Pollut. 2013, 176, 63-70. [CrossRef] [PubMed]

119. Pakrashi, S.; Jain, N.; Dalai, S.; Jayakumar, J.; Chandrasekaran, P.T.; Raichur, A.; Chandrasekaran, N.; Mukherjee, A. In Vivo Genotoxicity Assessment of Titanium Dioxide Nanoparticles by Allium cepa Root Tip Assay at High Exposure Concentrations. PLoS ONE 2014, 9, e87789. [CrossRef] [PubMed]

120. Burke, D.J.; Zhu, S.; Pablico-Lansigan, M.P.; Hewins, C.R.; Samia, A.C.S. Titanium oxide nanoparticle effects on composition of soil microbial communities and plant performance. Biol. Fertil. Soils 2014, 50, 1169-1173. [CrossRef]

121. Yang, F.; Liu, C.; Gao, F.; Su, M.; Wu, X.; Zheng, L.; Hong, F.; Yang, P. The Improvement of Spinach Growth by Nano-anatase TiO 2 Treatment Is Related to Nitrogen Photoreduction. Biol. Trace Elem. Res. 2007, 119, 77-88. [CrossRef]

122. Dehkourdi, E.H.; Mosavi, M. Effect of Anatase Nanoparticles $\left(\mathrm{TiO}_{2}\right)$ on Parsley Seed Germination (Petroselinum crispum) In Vitro. Biol. Trace Elem. Res. 2013, 155, 283-286. [CrossRef]

123. Chavan, S.; Sarangdhar, V.; Nadanathangam, V. Toxicological effects of $\mathrm{TiO}_{2}$ nanoparticles on plant growth promoting soil bacteria. Emerg. Contam. 2020, 6, 87-92. [CrossRef]

124. Simonin, M.; Martins, J.; LE Roux, X.; Uzu, G.; Calas, A.; Richaume, A. Toxicity of $\mathrm{TiO}_{2}$ nanoparticles on soil nitrification at environmentally relevant concentrations: Lack of classical dose-response relationships. Nanotoxicology 2017, 11, 247-255. [CrossRef]

125. Corsi, I.; Bergami, E.; Grassi, G. Behavior and Bio-Interactions of Anthropogenic Particles in Marine Environment for a More Realistic Ecological Risk Assessment. Front. Environ. Sci. 2020, 8, 60. [CrossRef]

126. Auffan, M.; Santaella, C.; Thiéry, A.; Pailles, C.; Rose, J.; Achouak, W.; Thill, A.; Masion, A.; Wiesner, M.R.; Bottero, J.Y. Ecotoxicity of inorganic nanoparticles: From unicellular organisms to invertebrates. In Encyclopedia of Nanotechnology; Springer: Dordrecht, The Netherlands, 2012; pp. 623-636. [CrossRef]

127. Wang, Y.; Zhu, X.; Lao, Y.; Lv, X.; Tao, Y.; Huang, B.; Wang, J.; Zhou, J.; Cai, Z. $\mathrm{TiO}_{2}$ nanoparticles in the marine environment: Physical effects responsible for the toxicity on algae Phaeodactylum tricornutum. Sci. Total Environ. 2016, 565, 818-826. [CrossRef]

128. Miller, R.J.; Bennett, S.; Keller, A.A.; Pease, S.; Lenihan, H.S. $\mathrm{TiO}_{2}$ Nanoparticles Are Phototoxic to Marine Phytoplankton. PLoS ONE 2012, 7, e30321. [CrossRef] [PubMed]

129. Della Torre, C.; Balbi, T.; Grassi, G.; Frenzilli, G.; Bernardeschi, M.; Smerilli, A.; Guidi, P.; Canesi, L.; Nigro, M.; Monaci, F.; et al. Titanium dioxide nanoparticles modulate the toxicological response to cadmium in the gills of Mytilus galloprovincialis. J. Hazard. Mater. 2015, 297, 92-100. [CrossRef] [PubMed] 
130. Banni, M.; Sforzini, S.; Balbi, T.; Corsi, I.; Viarengo, A.; Canesi, L. Combined effects of n-TiO 2 and 2,3,7,8-TCDD in Mytilus galloprovincialis digestive gland: A transcriptomic and immunohistochemical study. Environ. Res. 2016, 145, 135-144. [CrossRef]

131. Gornati, R.; Longo, A.; Rossi, F.; Maisano, M.; Sabatino, G.; Mauceri, A.; Bernardini, G.; Fasulo, S. Effects of titanium dioxide nanoparticle exposure in Mytilus galloprovincialis gills and digestive gland. Nanotoxicology 2016, 10, 807-817. [CrossRef] [PubMed]

132. Jimeno-Romero, A.; Oron, M.; Cajaraville, M.P.; Soto, M.; Marigómez, I. Nanoparticle size and combined toxicity of TiO ${ }_{2}$ and DSLS (surfactant) contribute to lysosomal responses in digestive cells of mussels exposed to $\mathrm{TiO}_{2}$ nanoparticles. Nanotoxicology 2016, 10, 1168-1176. [CrossRef]

133. Sureda, A.; Capó, X.; Busquets-Cortés, C.; Tejada, S. Acute exposure to sunscreen containing titanium induces an adaptive response and oxidative stress in Mytillus galloprovincialis. Ecotoxicol. Environ. Saf. 2018, 149, 58-63. [CrossRef]

134. Auguste, M.; Lasa, A.; Pallavicini, A.; Gualdi, S.; Vezzulli, L.; Canesi, L. Exposure to $\mathrm{TiO}_{2}$ nanoparticles induces shifts in the microbiota composition of Mytilus galloprovincialis hemolymph. Sci. Total Environ. 2019, 670, 129-137. [CrossRef]

135. Zhu, X.; Zhou, J.; Cai, Z. The toxicity and oxidative stress of $\mathrm{TiO}_{2}$ nanoparticles in marine abalone (Haliotis diversicolor supertexta). Mar. Pollut. Bull. 2011, 63, 334-338. [CrossRef]

136. Shang, Y.; Wu, F.; Wei, S.; Guo, W.; Chen, J.; Huang, W.; Hu, M.; Wang, Y. Specific dynamic action of mussels exposed to TiO 2 nanoparticles and seawater acidification. Chemosphere 2020, 241, 125104. [CrossRef]

137. Clemente, Z.; Castro, V.L.; Feitosa, L.; Lima, R.; Jonsson, C.; Maia, A.; Fraceto, L. Fish exposure to nano-TiO ${ }_{2}$ under different experimental conditions: Methodological aspects for nanoecotoxicology investigations. Sci. Total Environ. 2013, 463-464, 647-656. [CrossRef] [PubMed]

138. Naasz, S.; Altenburger, R.; Kühnel, D. Environmental mixtures of nanomaterials and chemicals: The Trojan-horse phenomenon and its relevance for ecotoxicity. Sci. Total Environ. 2018, 635, 1170-1181. [CrossRef] [PubMed]

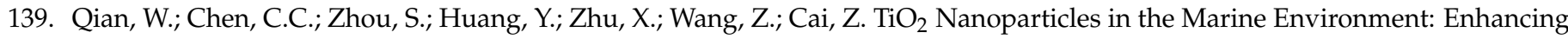
Bioconcentration, While Limiting Biotransformation of Arsenic in the Mussel Perna viridis. Environ. Sci. Technol. 2020, 54, 12254-12261. [CrossRef] [PubMed]

140. Balbi, T.; Smerilli, A.; Fabbri, R.; Ciacci, C.; Montagna, M.; Grasselli, E.; Brunelli, A.; Pojana, G.; Marcomini, A.; Gallo, G.; et al. Co-exposure to $\mathrm{n}-\mathrm{TiO}_{2}$ and $\mathrm{Cd} 2+$ results in interactive effects on biomarker responses but not in increased toxicity in the marine bivalve M. galloprovincialis. Sci. Total Environ. 2014, 493, 355-364. [CrossRef] [PubMed]

141. Wang, T.; Huang, X.; Jiang, X.; Hu, M.; Huang, W.; Wang, Y. Differential in vivo hemocyte responses to nano titanium dioxide in mussels: Effects of particle size. Aquat. Toxicol. 2019, 212, 28-36. [CrossRef]

142. Marisa, I.; Matozzo, V.; Martucci, A.; Franceschinis, E.; Brianese, N.; Marin, M.G. Bioaccumulation and effects of titanium dioxide nanoparticles and bulk in the clam Ruditapes philippinarum. Mar. Environ. Res. 2018, 136, 179-189. [CrossRef]

143. Guan, X.; Tang, Y.; Zha, S.; Han, Y.; Shi, W.; Ren, P.; Yan, M.; Pan, Q.; Hu, Y.; Fang, J.; et al. Exogenous Ca ${ }^{2+}$ mitigates the toxic effects of $\mathrm{TiO}_{2}$ nanoparticles on phagocytosis, cell viability, and apoptosis in haemocytes of a marine bivalve mollusk, Tegillarca granosa. Environ. Pollut. 2019, 252, 1764-1771. [CrossRef] [PubMed]

144. Shi, W.; Han, Y.; Guo, C.; Zhao, X.; Liu, S.; Su, W.; Zha, S.; Wang, Y.; Liu, G. Immunotoxicity of nanoparticle nTiO 2 to a commercial marine bivalve species, Tegillarca granosa. Fish Shellfish. Immunol. 2017, 66, 300-306. [CrossRef]

145. Gnatyshyna, L.; Falfushynska, H.; Horyn, O.; Khoma, V.; Martinyuk, V.; Mishchuk, O.; Mishchuk, N.; Stoliar, O. Biochemical responses of freshwater mussel Unio tumidus to titanium oxide nanoparticles, Bisphenol A, and their combination. Ecotoxicology 2019, 28, 923-937. [CrossRef]

146. Ziental, D.; Czarczynska-Goslinska, B.; Mlynarczyk, D.T.; Glowacka-Sobotta, A.; Stanisz, B.; Goslinski, T.; Sobotta, L. Titanium Dioxide Nanoparticles: Prospects and Applications in Medicine. Nanomaterials 2020, 10, 387. [CrossRef] [PubMed]

147. Hou, Z.; Zhang, Y.; Deng, K.; Chen, Y.; Li, X.; Deng, X.; Cheng, Z.; Lian, H.; Li, C.; Lin, J. UV-Emitting Upconversion-Based $\mathrm{TiO}_{2}$ Photosensitizing Nanoplatform: Near-Infrared Light Mediated in vivo Photodynamic Therapy via Mitochondria-Involved Apoptosis Pathway. ACS Nano 2015, 9, 2584-2599. [CrossRef]

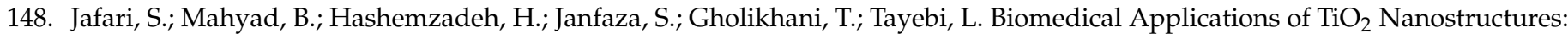
Recent Advances. Int. J. Nanomed. 2020, 15, 3447-3470. [CrossRef] [PubMed]

149. Suh, W.H.; Suslick, K.; Stucky, G.D.; Suh, Y.-H. Nanotechnology, nanotoxicology, and neuroscience. Prog. Neurobiol. 2009, 87, 133-170. [CrossRef] [PubMed]

150. De Angelis, I.; Barone, F.; Zijno, A.; Bizzarri, L.; Russo, M.T.; Pozzi, R.; Franchini, F.; Giudetti, G.; Uboldi, C.; Ponti, J.; et al. Comparative study of $\mathrm{ZnO}$ and $\mathrm{TiO}_{2}$ nanoparticles: Physicochemical characterisation and toxicological effects on human colon carcinoma cells. Nanotoxicology 2012, 7, 1361-1372. [CrossRef] [PubMed]

151. Zhang, A.-P.; Sun, Y.-P. Photocatalytic killing effect of $\mathrm{TiO}_{2}$ nanoparticles on Ls-174-t human colon carcinoma cells. World J. Gastroenterol. 2004, 10, 3191-3193. [CrossRef] [PubMed]

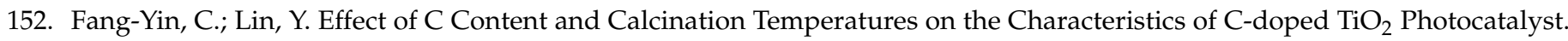
NSTI-Nanotech 2010, 1, 491-493.

153. Besha, A.T.; Liu, Y.; Bekele, D.N.; Dong, Z.; Naidu, R.; Gebremariam, G.N. Sustainability and environmental ethics for the application of engineered nanoparticles. Environ. Sci. Policy 2020, 103, 85-98. [CrossRef]

154. Horie, M.; Sugino, S.; Kato, H.; Tabei, Y.; Nakamura, A.; Yoshida, Y. Does photocatalytic activity of $\mathrm{TiO}_{2}$ nanoparticles correspond to photo-cytotoxicity? Cellular uptake of $\mathrm{TiO}_{2}$ nanoparticles is important in their photo-cytotoxicity. Toxicol. Mech. Methods 2016, 26,1-11. [CrossRef] 
155. Zhang, L.W.; Monteiro-Riviere, N.A. Toxicity assessment of six titanium dioxide nanoparticles in human epidermal keratinocytes. Cutan. Ocul. Toxicol. 2019, 38, 66-80. [CrossRef]

156. Rashid, M.M.; Simončič, B.; Tomšič, B. Recent advances in $\mathrm{TiO}_{2}$-functionalized textile surfaces. Surf. Interfaces 2021, $22,100890$. [CrossRef]

157. Miyani, V.A.; Hughes, M.F. Assessment of the in vitro dermal irritation potential of cerium, silver, and titanium nanoparticles in a human skin equivalent model. Cutan. Ocul. Toxicol. 2017, 36, 145-151. [CrossRef] [PubMed]

158. Stan, M.S.; Nica, I.C.; Popa, M.; Chifiriuc, M.C.; Iordache, O.; Dumitrescu, I.; Diamandescu, L.; Dinischiotu, A. Reduced graphene oxide $/ \mathrm{TiO}_{2}$ nanocomposites coating of cotton fabrics with antibacterial and self-cleaning properties. J. Ind. Text. 2018, 49, 277-293. [CrossRef] 